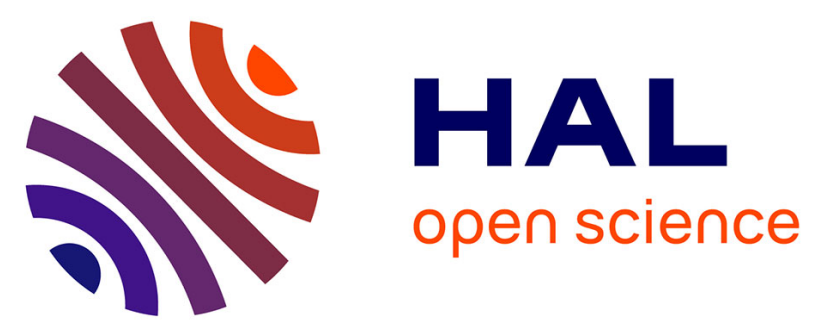

\title{
The Buday'ah Formation, Sultanate of Oman: A Middle Permian to Early Triassic oceanic record of the Neotethys and the late Induan microsphere bloom
}

Aymon Baud, Sylvain Richoz, Benoit Beauchamp, Fabrice Cordey, S. Grasby, Charles M. Henderson, Leopold Krystyn, Alda Nicora

\section{To cite this version:}

Aymon Baud, Sylvain Richoz, Benoit Beauchamp, Fabrice Cordey, S. Grasby, et al.. The Buday'ah Formation, Sultanate of Oman: A Middle Permian to Early Triassic oceanic record of the Neotethys and the late Induan microsphere bloom. Journal of Southeast Asian earth sciences, 2012, 43 (1), pp.130-144. 10.1016/j.jseaes.2011.08.016 . hal-00660465

\section{HAL Id: hal-00660465 https://hal.science/hal-00660465}

Submitted on 29 Jun 2021

HAL is a multi-disciplinary open access archive for the deposit and dissemination of scientific research documents, whether they are published or not. The documents may come from teaching and research institutions in France or abroad, or from public or private research centers.
L'archive ouverte pluridisciplinaire HAL, est destinée au dépôt et à la diffusion de documents scientifiques de niveau recherche, publiés ou non, émanant des établissements d'enseignement et de recherche français ou étrangers, des laboratoires publics ou privés. 


\title{
The Buday'ah Formation, Sultanate of Oman: A Middle Permian to Early Triassic oceanic record of the Neotethys and the late Induan microsphere bloom
}

\author{
Aymon Baud ${ }^{\mathrm{a}, *}$, Sylvain Richoz ${ }^{\mathrm{b}}$, Benoit Beauchamp ${ }^{\mathrm{c}}$, Fabrice Cordey ${ }^{\mathrm{d}}$, Stephen Grasby ${ }^{\mathrm{e}}$, \\ Charles M. Henderson ${ }^{c}$, Leopold Krystyn ${ }^{\mathrm{f}}$, Alda Nicora ${ }^{\mathrm{g}}$

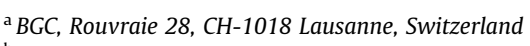 \\ ${ }^{\mathrm{b}}$ Commission for the Palaeontological and Stratigraphical Research of Austria, Austrian Academyrs of Sciences c/o Institute of Earth Sciences, University of Graz, \\ Heinrichstraße 26, $8010 \mathrm{Graz}$, Austria \\ ${ }^{\mathrm{c}}$ Department of Geoscience, University of Calgary, 2500 University Drive, N.W.Calgary, Alberta, Canada T2N 1N4 \\ d Département Sciences de la Terre, CNRS UMR 5125 Paléoenvironnements Paléobiosphère, Université Lyon 1, 69622 Villeurbanne, France

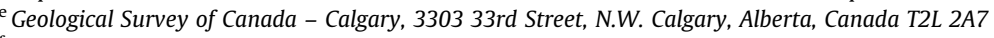 \\ ${ }^{\mathrm{f}}$ Department of Palaeontology, Vienna University, Althanstrasse 14, 1090 Vienna, Austria \\ ${ }^{\mathrm{g}}$ Dipartimento di Scienze della Terra, Universita degli Studi di Milano, Via Mangiagalli 34, Milano 20133, Italy
}

\section{A R T I C L E I N F O}

\section{Article history:}

Received 15 February 2011

Received in revised form 19 July 2011

Accepted 19 August 2011

Available online $\mathrm{xxxx}$

Dedicated to Jean Marcoux

\section{Keywords:}

Permian

Lower Triassic

Chert

Radiolaria

Conodonts

Chemostratigraphy

Platy and papery limestone

\begin{abstract}
A B S T R A C T
The Middle Permian to Lower Triassic Buday'ah section, exposed in the Oman Mountains, is the first deepsea section to be described in the Neotethys. The oceanic sediments were deposited along the southern Tethys margin in the newly formed Hawasina Basin. It is one of the few places where true Tethyan Permian radiolarites are exposed that allow the documentation of CCD evolution through time. The succession begins as oceanic crust pillow basalt with red ammonoid-rich pelagic limestone occurring both above and within inter-pillow cavities; the new occurrence of Clarkina postbitteri hongshuiensis indicates a late Capitanian age for the carbonate. The sharp change to overlying late Capitanian to Changhsingian radiolarite reflects rapid subsidence about 10 Myrs after initial continental breakup that resulted in the formation of the Neotethys Ocean. New conodonts indicate that the Permian-Triassic boundary succession occurs in the first platy lime mudstone beds above a Changhsingian siliceous to calcareous shale unit. The platy lime mudstone beds include an Upper Griesbachian bloom of calcite filled spheres (radiolarians?) that marks a potential world-wide event. New conodonts indicate an early Olenekian age for overlying grey papery limestone that are devoid of both macrofossils and trace fossils indicating that recovery from the Late Permian extinction has not yet progressed within this deep-water environment.

$\delta^{13} \mathrm{C}_{\text {org }}$, isotope values have not been disturbed and they show a negative shift just below the PermianTriassic transition and a second one at the parvus zone level above. The Buday'ah succession may represent the most distal and probably deepest Permian and Lower Triassic depositional sequence within the basin.
\end{abstract}

(c) 2011 Elsevier Ltd. All rights reserved.

\section{Introduction and geologic setting}

At the end of the Paleozoic the continents were amalgamated to form the Pangean supercontinent; in its southern half, Oman and the Arabian Peninsula as well as Africa, Iran, India etc. formed part of the Gondwana continent. During the Late Carboniferous-Earliest Permian period, this part of Gondwana was subjected to glaciation (Al Khlata tillite in Oman, Angiolini et al., 2003a).

The Neotethys Ocean opened with the northward drifting of the Iran/Mega Lhasa microcontinent (Baud et al., 1993, 2001a,b), following a rifting - extensional phase beginning during either the

\footnotetext{
* Corresponding author. Tel./fax: +41216478973.

E-mail address: aymon.baud@unil.ch (A. Baud).
}

Sakmarian (see Saidi et al., 1997; Besse et al., 1998; Angiolini et al., 2003a,b; Maury et al., 2003) or the Roadian-Wordian (hypothesis developed by Baud et al. (1993, 2001a,b), Pillevuit (1993), Pillevuit et al. (1997) and preferred in this paper). Thermal subsidence, associated with the breakup of the continental margin, is well recorded in the Capitanian carbonate succession and continued during the Lopingian. Tectonic instability of the margin, with block tilting, platform drowning and (fault) breccia deposits characterize the Early Triassic with the main climax during the Dienerian to Smithian. A renewed tectonic instability with plume related volcanism started offshore during the Carnian with the creation of atoll-like isolated carbonate platforms (Kawr) and the opening of a new basin (Umar). At the end of the Triassic, all known parts of the continental margin and adjacent ocean and atoll areas were finalized. 


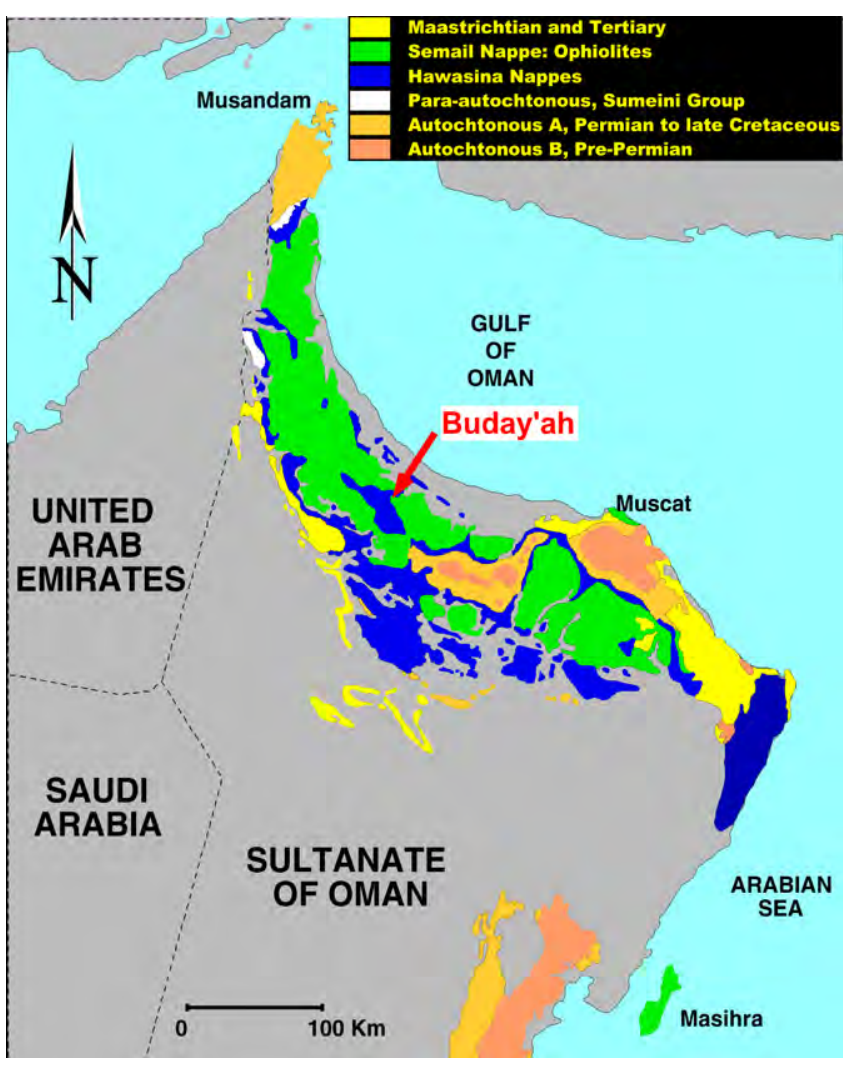

Fig. 1. Geological sketch of the Oman Mountains.

Middle Permian to Lower Triassic rocks are exposed at Buday'ah in the Oman Mountains (Fig. 1). These volcanic and sedimentary rocks accumulated in a deep oceanic setting along the southern margin of the Tethys. Located in the northeast part of the Hawasina Window (Ibri map, Béchennec et al., 1992c), this locality (coord: N23 $44^{\prime} 41^{\prime \prime}$, E56 $54^{\prime} 21^{\prime \prime}$; Fig. 2A) is a rare occurrence of unequivocal Tethyan Permian radiolarite. The Buday'ah section has been previously described in field guidebooks and in a thesis produced at the University of Lausanne, Switzerland (Baud et al., 2001b, 2010; Richoz et al., 2005; Richoz, 2006) but not yet published to the international community. This paper characterizes for the first time a deep water Neotethys succession in order to refine the tectono-sedimentary evolution of the Late Permian to Early Triassic Neotethys Ocean in the Oman region.

Compared with other deep water occurrences belonging to the Hamrat Duru Group (Wadi Wasit, Nakhl, Rustaq), the Buday'ah locality is the most distal and probably deepest Permian succession of the basin as suggested by a near complete absence of carbonate sediments above the basal red limestone. Shallow water debris rarely occurs in the red limestone. This lithologic unit differs considerably from the Al Jil Formation defined by Béchennec (1988) at the base of Djebel Misht and near Taw in the west-central Oman Mountains (Seeb map area) and partly redefined in the same area as part of a 1:250,000-scale mapping exercise (Béchennec et al., 1992a). On the basis of the present study, we are proposing a new name for this unit, the Buday'ah Formation, which is composed of eight informal lithologic units (Fig. 3).

\section{Designation and description of the Buday'ah Formation}

\subsection{Type section}

The composite type section area is located within the northeast part of the Hawasina window at the following coordinates (WGS
84 datum): N234 $44^{\prime} 41^{\prime \prime}$, E56 $54^{\prime} 21^{\prime \prime}$. Field photograph of the study area is shown in Fig. $2 \mathrm{~A}$ and the three localities of the composite type section in Fig. 4 (Locality 1: N23 $44^{\prime} 41^{\prime \prime}$, E56 $54^{\prime} 21^{\prime \prime}$; Locality 2:

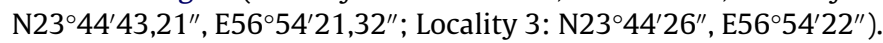

\subsection{Stratigraphic relationships, thickness and age}

The formation represents a distinctive mappable unit with the Hawasina window. A composite stratigraphic section is depicted in Fig. 3 based on three different exposures (Locality 1, 2, 3; Fig. 4) indicating a $30 \mathrm{~m}$ thick sedimentary succession above the pillow lava unit that is at least $60 \mathrm{~m}$ thick. The base of the formation is overturned and has been overthrust by the obducted Cretaceous ophiolite complex. The top is stratigraphically overlain by a younger Triassic deep-water succession within the Hawasina window. The formation consists of 8 informal units that are described below. These units range in age from Capitanian (Middle Permian) to Olenekian (Early Triassic) as determined from ammonoids, conodonts and radiolarians.

\subsection{Unit 1 description}

Unit 1 is truncated at the base by a fault. The unit consists of pillow basalt that provided a foundation for the sedimentary succession above. The basalt outcrops in two hills, one roughly $1 \mathrm{~km}$ across and the other several kms across. Unit 1 is composed of dark-green to brown, slightly amygdaloidal, pillow basalts. Pillows range in diameter from $20 \mathrm{~cm}$ to $1 \mathrm{~m}$ and have aphyric cores and rims with local plagioclase phenocrysts.

According to Maury in Baud et al. (2001b) and Maury et al. (2003), the basalt has a microlitic texture and is generally spherulitic and locally porphyritic. The plagioclase is occurring mainly as sheafs of skeletal microlites, but also in spherulites and, in places, as phenocrysts. Also present are rare clinopyroxene occurring as fine prisms and phenocrysts replaced by carbonate and oxides, Fe-Ti oxides occurring interstitially and as elongate skeletal crystals, and carbonate in small amygdales. Data on rare earth elements (REE), thorium and high field strength elements on two basalt samples at Buday'ah show transitional and enriched MORB signatures (Maury et al., 2003; Lapierre et al., 2004). This association is interpreted to have erupted in the Hawasina Basin away from the continent, in a true oceanic setting located near hot spots (Lapierre et al., 2004).

\subsection{Unit 2 description}

In different parts of the pillow lava succession, inter-pillow cavities are filled with red lime-mudstone that has yielded ammonoids. Unit 2 is a dm thick red ammonoid-bearing limestone (Fig. 2B), with lateral variation of thickness from 0 to $1.2 \mathrm{~m}$. This limestone unit is a typical condensed cephalopod pelagic limestone known as Hallstatt limestone facies in the Triassic of the Eastern Alps, well known since the 19th Century from the famous Mojsisovics studies $(1892,1893)$. Thin coatings of black manganese oxide minerals locally line large ammonoid shells (Fig. 2C). Very rare resedimented clasts of reefal origin (Fig. 2D) occur within in the red limestone unit. De Wever et al. (1988) reported Fenestellidae (bryozoa), corals, crinoids, gastropods, ostracods and calcareous algae from these clasts.

\subsection{Unit 3 description}

Unit 3 of the Buday'ah Formation at Locality 2 consists of a succession of thin nodular brownish mudstone, siliceous shale and red radiolarian chert resting conformably on the red limestone, or directly on the basalt over tens of meters laterally. This unit displays considerable lateral change in thickness ranging from 4 

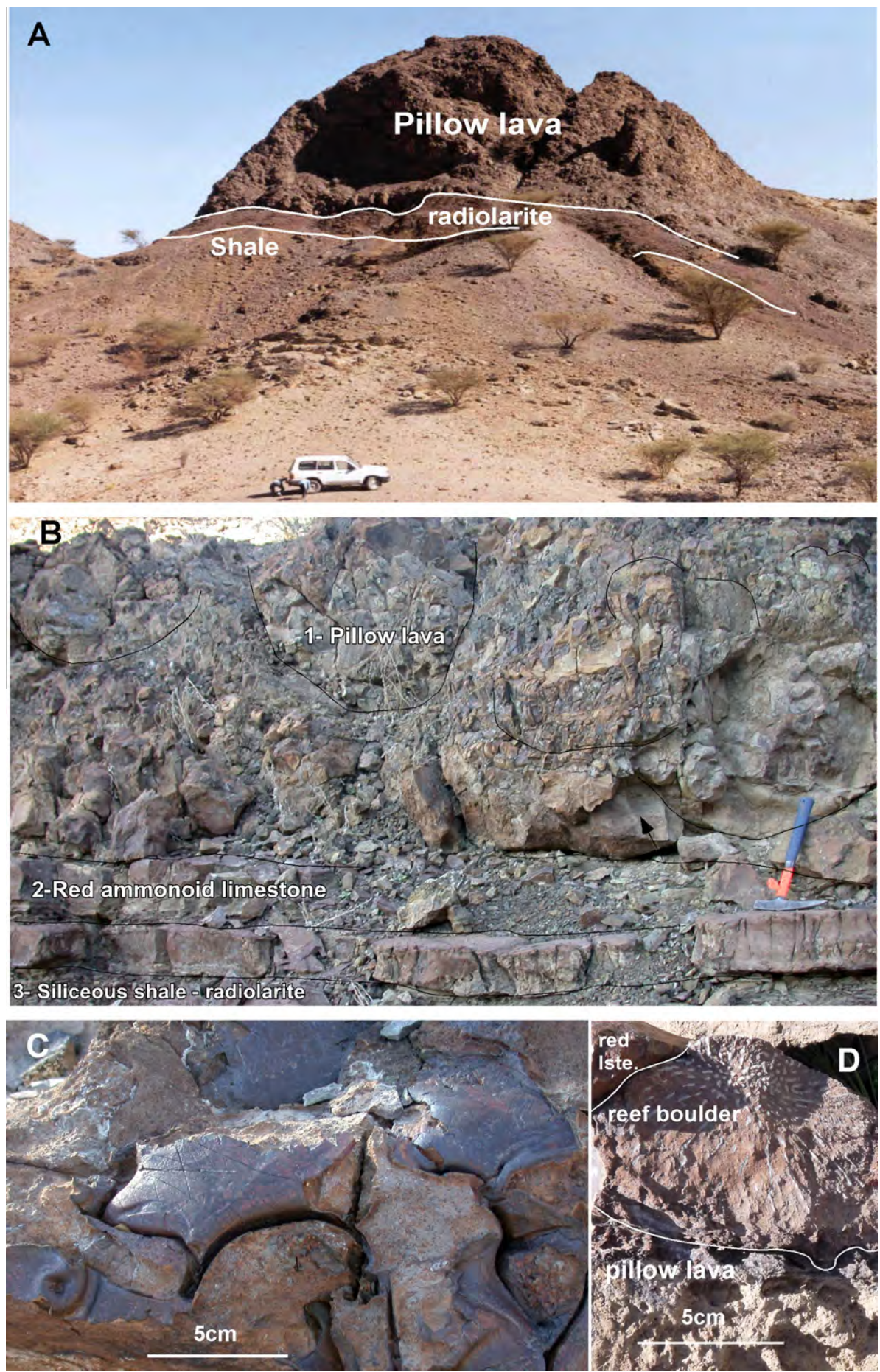

Fig. 2. (A) View of Buday'ah locality from the South. Overturned succession of MORB-type lava (Buday'ah unit 1, top of the front hill) and Upper Permian radiolarian chert and shale below (Buday'ah units 3-4). (photo J. Marcoux). (B) Overturned section of the basal part of the Buday'ah Formation with the contact between units 1, 2 and 3. Arrow points to lenses of limestone between pillows. (C) Surface of red limestone containing large ammonoids with thin coatings of black manganese oxide minerals lining the original shells. (D) Reef boulder on pillow-lava and red limestone. Scale bar, $5 \mathrm{~cm}$.

to $8.5 \mathrm{~m}$. Radiolarians were studied in one of the thickest section (overturned section B, Fig. 5), which is directly in contact with the limestone-bearing pillow-basalt and consists of red shale and red chert beds $(2 \mathrm{~m})$, yellow shale and black siliceous mudstone and siltstone ( $2 \mathrm{~m}$, thin section in Fig. 7A), yellow radiolarite $(0.5 \mathrm{~m})$, red radiolarite $(2 \mathrm{~m})$, yellowish shale and chert beds $(2 \mathrm{~m})$.

\subsection{Unit 4 description}

Unit 4 overlies the red radiolarite and consists of monotonous dark grey, laminated siliceous shale. The unit is about $2 \mathrm{~m}$ thick. The end-Permian extinction event is believed to correspond more or less with the top of this unit, which is associated with the disappearance of biogenic silica.

Please cite this article in press as: Baud, A., et al. The Buday'ah Formation, Sultanate of Oman: A Middle Permian to Early Triassic oceanic record of the Neotethys and the late Induan microsphere bloom. Journal of Asian Earth Sciences (2011), doi:10.1016/j.jseaes.2011.08.016 


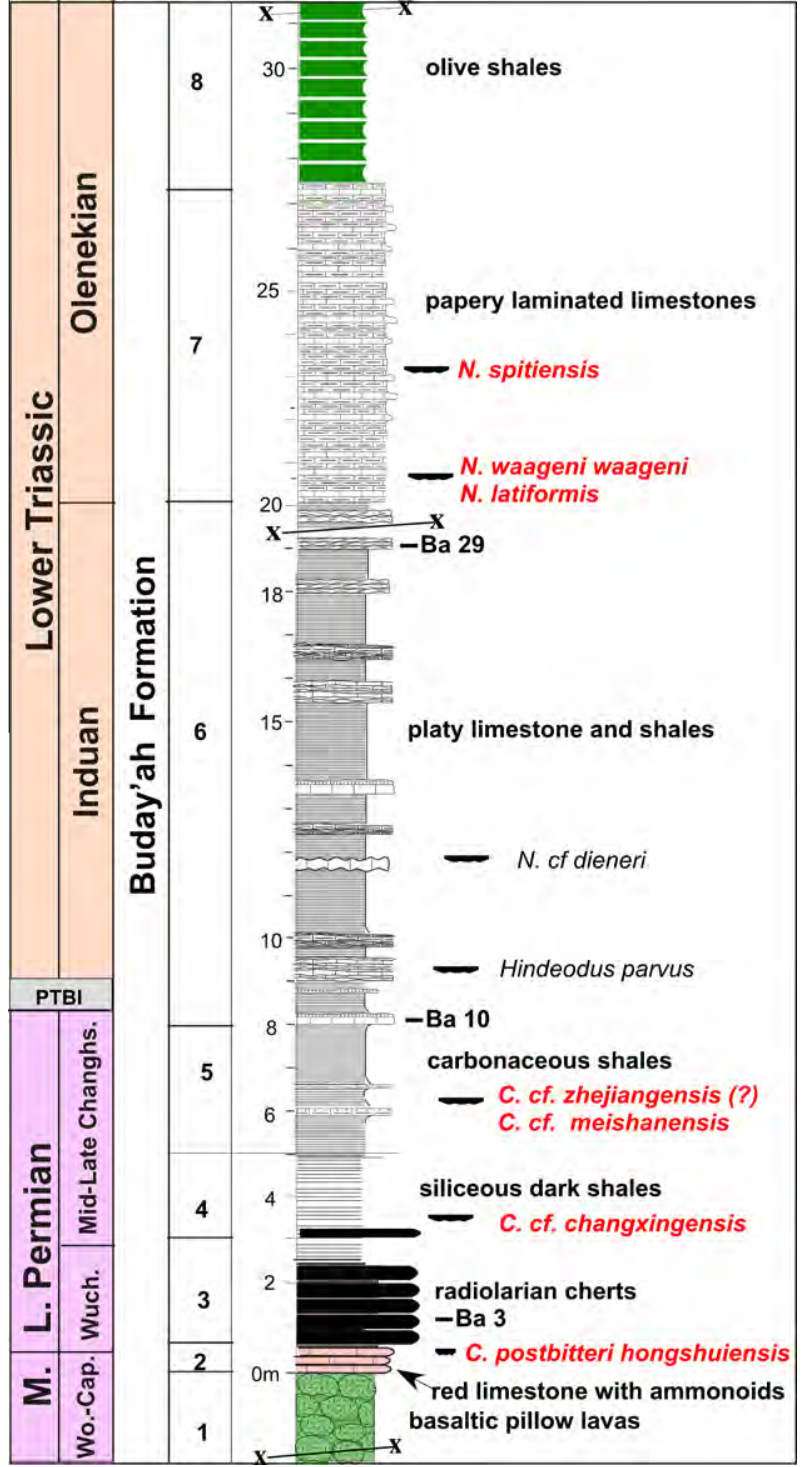

Fig. 3. Stratigraphic sketch of the Buday'ah composite section with the new conodont findings (in red). (For interpretation of the references to colour in this figure legend, the reader is referred to the web version of this article.)

\subsection{Unit 5 description}

A lithologic change occurs sharply at the base of Unit 5 (about 3 m thick, Figs. 3 and 6A) with the appearance of light calcareous shale with $2-3 \mathrm{~cm}$ thick lime mudstone interbeds.

\subsection{Unit 6 description}

Unit 6 is $11 \mathrm{~m}$ thick. The basal part of the unit ( 6 in Fig. $6 \mathrm{~A}$ ) is composed of a $20 \mathrm{~cm}$-thick micritic grey limestone bed, consisting of a bioturbated and laminated lime mudstone, (Fig. 7B) capped by $5 \mathrm{~cm}$ of breccias and followed by $80 \mathrm{~cm}$ of light calcareous shale. The main body of the unit consists of alternating yellow marly shale with $\mathrm{cm}$ thick platy limestone and thicker $(\mathrm{dm})$ marly limestone (Fig. 6B). The second platy lime mudstone contains conodonts (listed in Section 3.3 and in Richoz (2006)). Close-ups of the bedding and graded depositional (turbidite?) facies are shown in Fig. 6C and D. The microfacies of the platy limestone comprise lime mudstone that contains rare calcispheres at the base. Calcispheres become abundant near the top of the unit where they range from 0.05 to $0.2 \mathrm{~mm}$ in diameter (Fig. 7C and D).
The top of Unit 6 is tectonically truncated at locality 2, but the transition with Unit 7 is can be observed laterally (locality 3; Fig. 8A).

\subsection{Unit 7 description}

This unit consists of a very thin-bedded finely laminated grey lime mudstone (papery limestone, Fig. 8A and B) that is completely devoid of macrofossils and trace fossils indicating that recovery from the Late Permian extinction has not yet occurred at this locality. Only rare conodonts are present (described in Section 3.3). The finely laminated lime mudstone is arranged in a series of micro-cycles that start with light-colored paper-thin beds of lime mudstone (Fig. 8C). This facies has some similarities with a basal Triassic limestone unit at Wadi Maqam (Richoz et al., 2005).

\subsection{Unit 8 description}

Unit 8 comprises about $4 \mathrm{~m}$ of olive colored shale (Fig. 3 and photo in Fig. 8A). The top of the unit is tectonically truncated. Unit 8 marks a shift from fine carbonate mud to terrigenous clay. A similar transition is recorded in the upper Olenekian slope deposits of the Sumeini nappe where Spathian shale (Maqam D) overlies upper Smithian platy limestone (Maqam C; Richoz et al. 2005). In Tulong (S. Tibet) there is a similar succession with Smithian thinbedded limestone overlain by Spathian green shale (Brühwiler et al., 2009). However, thin limestone beds occur in the basal part of the shale succession at both of these localities. Such limestone beds are not found at the base of Unit 8 at Buday'ah.

\section{Biostratigraphy and new data}

A revised biostratigraphy is reported below based on the reexamination of old collections, reinterpretation of the fossil zonation, and new findings including the recovery of new conodont specimens.

\subsection{Foraminifera}

De Wever et al. (1988) recovered microfauna from resedimented reefal clasts in Unit 2 that consist of Neoschwagerina margaritae, Stafella sp., Nankinella sp., Pachyploia sp. and Geinitzina sp., and correlated it to late Murghabian (Wordian). However, according to the new zonation of Gaillot and Vachard (2007), similar foraminiferal assemblages are now interpreted as Capitanian in age.

\subsection{Ammonoids}

The red lime mudstone of Unit 2, which occurs within interpillow cavities yielded the ammonoids Timorites sp. and Waagenoceras cf. mojsisovicsi (det. L. Krystyn, Fig. 9) that provide a Late Wordian-Capitanian age for the infilling of the volcanic sequence. The well-preserved Waagenoceras specimen shows a $270^{\circ}$ long body chamber with, except for the Sicilian type specimen of the species (Gemmellaro, 1887), ongoing constrictions. It differs further in a slimmer cross-section ( $W=76 \%$ of $\mathrm{D}$ ) and a straight external suture. The wholly septate and somewhat fragmentary Timorites has a highly indented suture line with the genus-typical "mushroom-like" first lateral saddle sensu Zhakarov and Ehiro (2010) and a widely open umbilicus ( $U=28 \%$ of D). Evolute Timorites like the present form are here considered as typically Capitanian in age. Zhakarov and Ehiro (2010) also include in Timorites forms with narrow, Cyclolobus-like, umbilicus (i.e. Hanieloceras sensu others) that indicate a late Wordian to early Wuchapingian range for this genus. Waagenoceras ranges from Upper Roadian to 


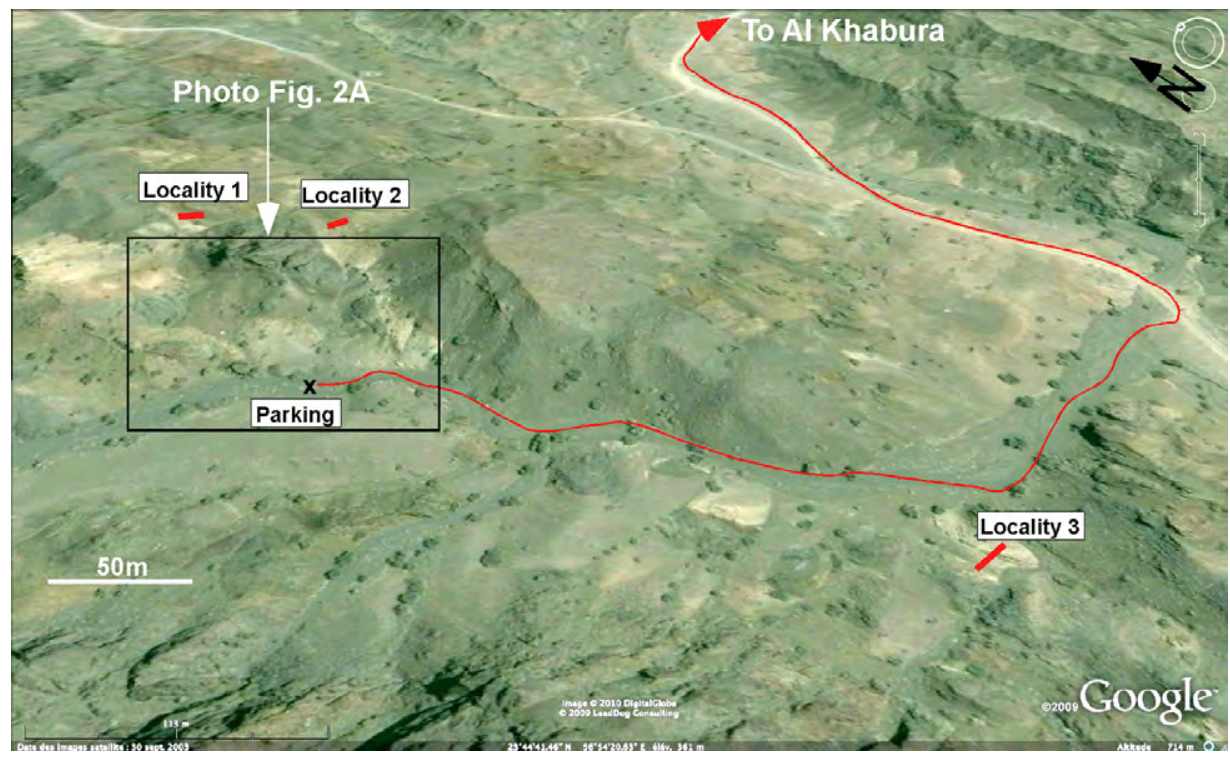

Fig. 4. Oblique satellite view of the Buday'ah area (Google Earth $\odot$ ) with location of the three partial sections of the new Buday'ah Formation (Localities 1,2 and 3 , coordinates in the texte).

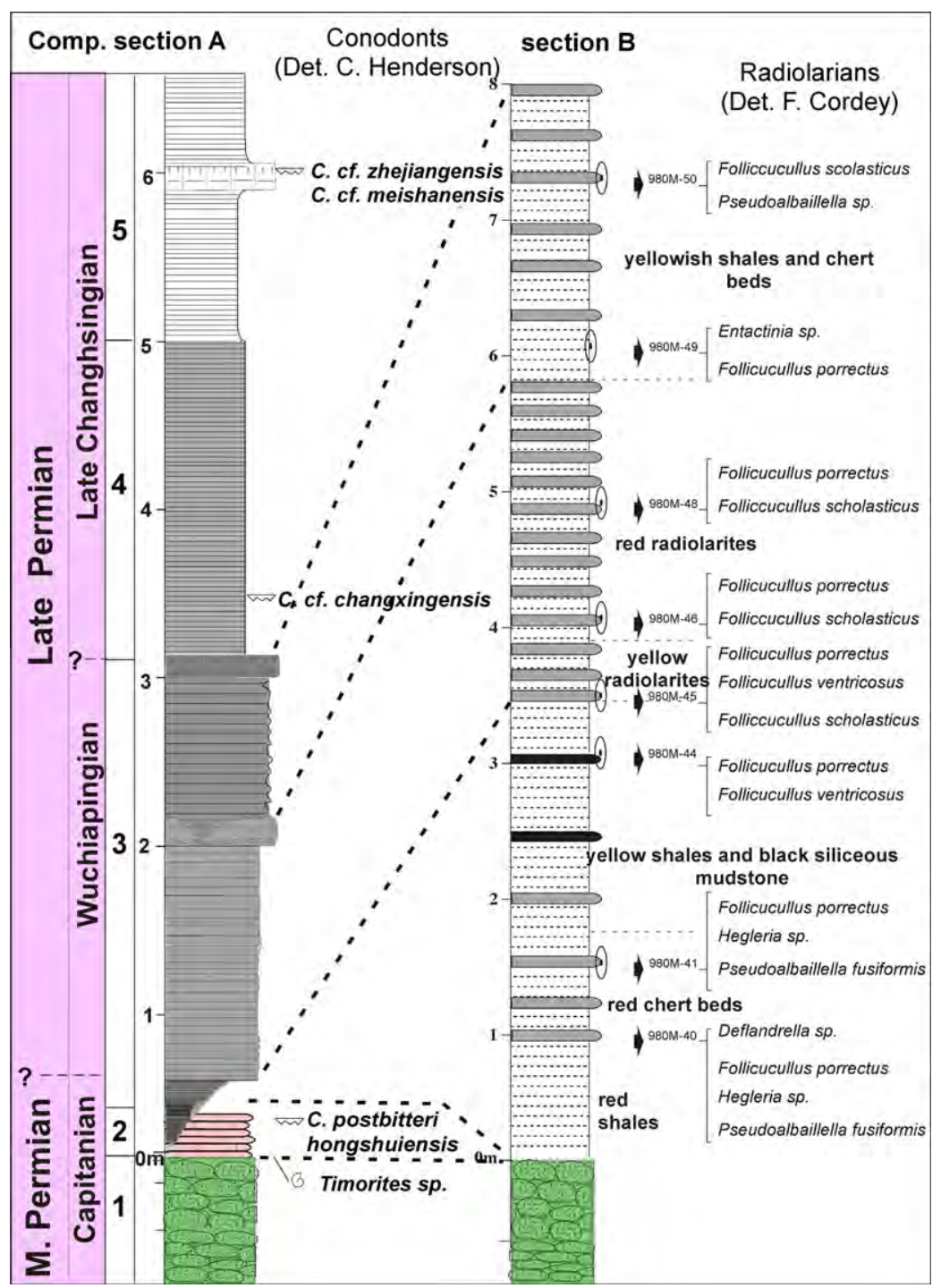

Fig. 5. Stratigraphy of the Lower Buday'ah Formation (Units 1-4) with the correlation between sections A and B. Section B has been presented by F. Cordey (Fig. 17 in Baud et al., 2001b).

Please cite this article in press as: Baud, A., et al. The Buday'ah Formation, Sultanate of Oman: A Middle Permian to Early Triassic oceanic record of the Neotethys and the late Induan microsphere bloom. Journal of Asian Earth Sciences (2011), doi:10.1016/j.jseaes.2011.08.016 

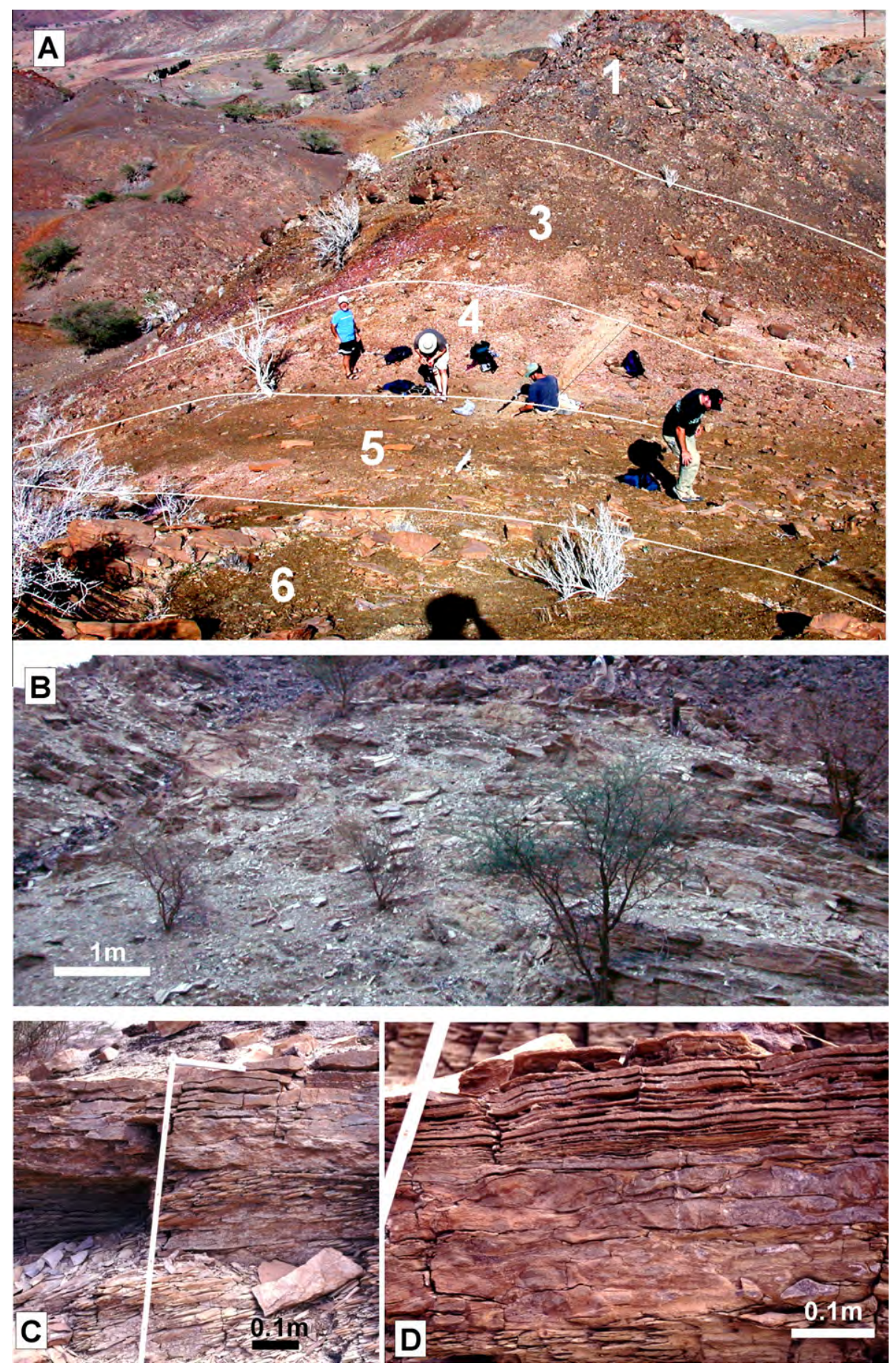

Fig. 6. (A) View of locality 2. 1 - Overturned succession of MORB-type lava (Unit 1); 3 - Middle to Late Permian radiolarian chert; 3 - siliceous shale (part of the Unit 3); 4 siliceous shales (Unit 4); 5 - carbonaceous shale (Unit 5); 6 - brown weathered platy limestone and shale (Unit 6). The Permian-Triassic boundary interval (PTBI) is within Unit 5. (B) Outcrop picture of the platy limestone and shale of Unit 6. (C) Close up on limestone sequence. (D) Close up from beds thinning upward bedding (distal lime mud silty turbidite.

Capitanian, while Lower Roadian reports of that genus can be referred to Demarezites.

\subsection{Conodont fauna}

Near the top of the red limestones (Unit 2) C.M. Henderson and A. Nicora have recovered a new fauna yielding Clarkina postbitteri hongshuiensis of latest Capitanian age. Variability within these specimens (Fig. 10) is closely comparable to type material of this subspecies illustrated by Henderson et al. (2002).

Near the base of Unit 4 ( $0.5 \mathrm{~m}$ above base), a conodont sample yielded Clarkina cf. changxingensis (det. C.M. Henderson) of midChanghsingian age.

Some $1.2 \mathrm{~m}$ above the base of the Unit 5, another sample provided two fragments attributed to Clarkina cf. meishanensis and one specimen of Clarkina zhejiangensis (?) (det. C. Henderson) that span the Permian-Triassic boundary (Fig. 3). 


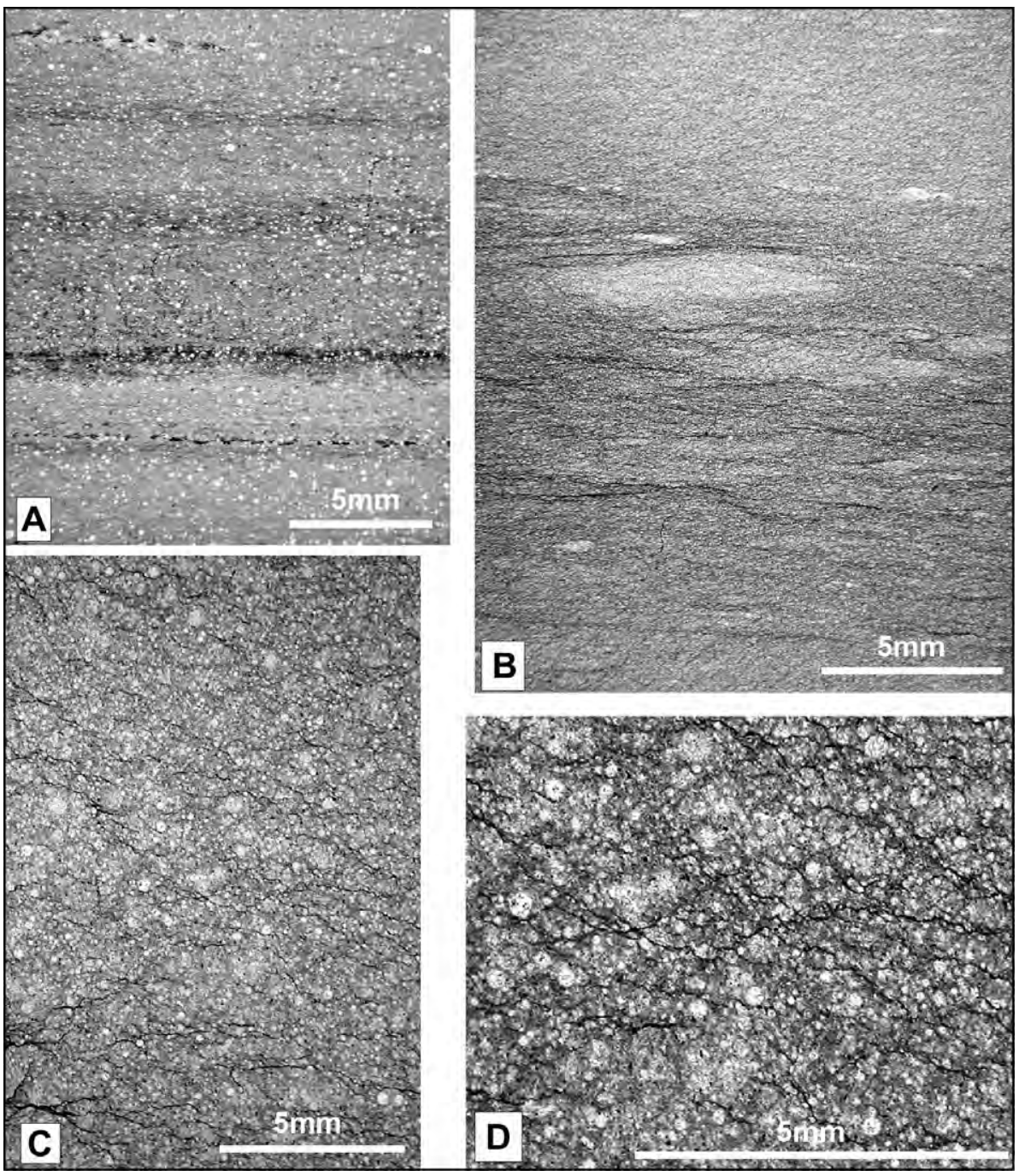

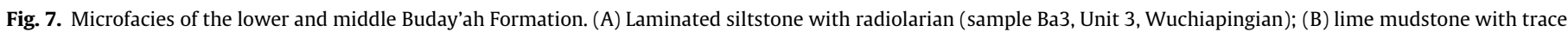

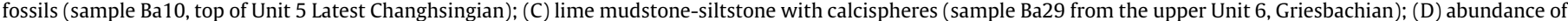

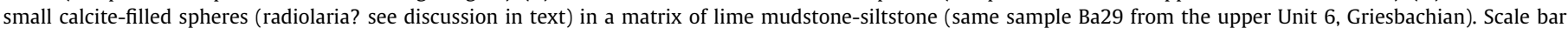
$5 \mathrm{~mm}$.

Conodonts were reported in, but not illustrated by Richoz et al. (2005) and Richoz (2006) from Unit 6 (Kozur pers. comm. 2003): including a badly preserved specimen of Hindeodus cf. parvus $1 \mathrm{~m}$ above the base and $3 \mathrm{~m}$ higher Neospathodus dieneri.

The papery limestone of Unit 7 yielded Neospathodus waggeni waageni (det. C. Henderson and A. Nicora) and Novispathodus latiformis near the base and Neospathodus spitiensis near the middle of the unit (Fig. 8A). These species are typical of the Smithian ammonoid Euflemingites romunderi Zone (Orchard and Zonneveld, 2009) and they named $N$. latiformis as a recently described species for a variant of $N$. waageni sensu lato.

\subsection{Radiolarian fauna (Fig. 11) and new radiolarian zonation}

Unit 3 was previously dated as Wordian on the basis of radiolarians (Béchennec, 1988; De Wever et al., 1988). According to F. Cordey (in Baud et al. (2001a,b)), the radiolarites of section B in Fig. 5 were assigned an age ranging from Wordian to Capitanian on the basis of 9 samples correlated with Pseudoalbaillella fusiformis-Pseudoalbaillella globosa and Follicucullus ventricosusFollicucullus scholasticus assemblage zones.
However, since radiolarites from Unit 3 overlie the bed yielding Clarkina postbitteri hongshuiensis of latest Capitanian age, the radiolarian assemblages is inferred to be latest Capitanian or Wuchiapingian in age. This is consistent with the fact that, for the last decade, radiolarian studies have shown that some species have a longer age range than previously established. The $F$. ventricosusF. scholasticus assemblage zone, previously considered as restricted to the Capitanian (see for instance Cordey, 1998, and references therein), has progressively been extended into the Wuchiapingian, based on new discoveries and better correlations (Kuwahara et al., 2004; Sperling and Ingle, 2006). Our topmost sample (OM98-50) contains F. scholasticus, which has a long Middle-Late Permian range and therefore does not provide an adequate age determination for the top part of the radiolarite succession.

Small calcite-filled spheres (radiolaria? Fig. 7D) are present in the Triassic lime mudstone beds of the Unit 6. These "spheroids" lack any ornamentation and seem to be widespread in deepwater sediments during the Induan. They were attributed to a so-called spheroid biozone by Yao and Kuwahara (2000). Sperling and Ingle (2006) also reported this event in the Black Rock terrane series of Nevada. A similar "microspheres" horizon is reported in Unit 1b at Tulong (S. Tibet, Brühwiler et al., 2009) and at the base of the 

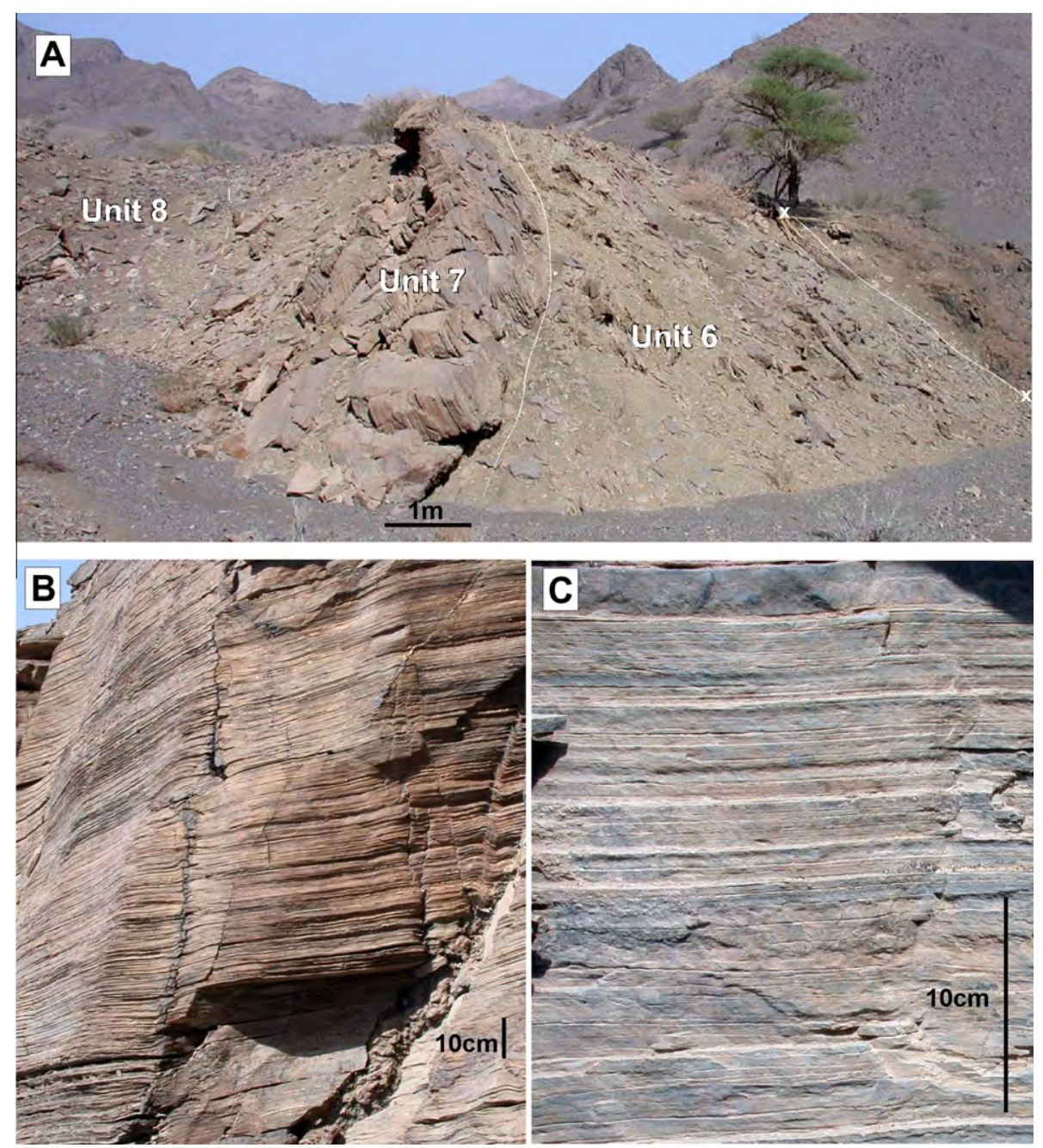

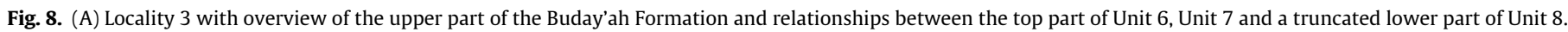
(B) The typical papery limestone facies. (C) Detailed view of finely laminated lime mudstone showing micro-cycles starting with light lime mudstone.

Feixianguan Formation of Laolongdong (Sichuan, China, Wignall and Twitchett, 1996).

\section{Chemostratigraphy}

The $\delta^{13} \mathrm{C}_{\mathrm{org}}, \delta^{13} \mathrm{C}_{\mathrm{carb}},{ }^{87} \mathrm{Sr} /{ }^{86} \mathrm{Sr}$, TOC and trace element concentrations (Mo, $\mathrm{V}, \mathrm{Cr}, \mathrm{Ni}$, and $\mathrm{Fe}$ ) were measured in this section.

\subsection{Methods}

For $\delta^{13} \mathrm{C}_{\text {carb }}$ analyses, powders were produced from micrite samples using a diamond-tipped drill. Hand specimens were carefully examined to avoid cracks, veins and weathering features and drilled on the blanks of thin sections. The 26 samples were analyzed using an automated carbonate preparation system (Gas bench) connected to a DeltaplusXL mass spectrometer (Spötl and Vennemann, 2003) at Lausanne University. Reproducibility of replicate analyses was better than $\pm 0.1 \%$ o for standards and $\pm 0.15 \%$ o for sediment samples for both carbon and oxygen isotope values. All isotope results are reported using the conventional $\delta$ notation, defined as per mil (\%o) deviation vs. VPDB. The numerical data are found in Richoz (2006).

${ }^{87} \mathrm{Sr} /{ }^{86} \mathrm{Sr}$ analyses were conducted on carbonate bulk rock with reduced clay amounts. Hand specimens were carefully examined to avoid cracks, veins and weathering features and crashed into a powder. This powder was analyzed at Bern University on Ion Instrument ${ }^{\circledR}$ AVCO.

Total organic carbon (TOC) was measured by ROCKEVAL. Elemental determinations are based on total dissolution of the sample using nitric, perchloric and hydrofluoric acids followed by a lithium metaborate fusion of any residual material. Samples were analyzed by ICP emission and mass spectrometry. For determination of $\delta^{13} \mathrm{C}_{\mathrm{org}}$, samples were washed with hydrochloric acid, and rinsed with distilled water to remove any carbonate before determination of $\delta^{13} \mathrm{C}$ of organic carbon $\left(\delta^{13} \mathrm{C}_{\mathrm{org}} \pm 0.2 \%\right.$ ) .

\section{2. $\delta^{13} C_{\text {carb }}$ results (Richoz, 2006)}

Permian cherty carbonates have $\delta^{13} \mathrm{C}_{\text {carb }}$ values of $-7.1 \%$ and $-6.0 \%$; these values slowly increase to reach $-1.0 \%$ in the lower part of unit 7. The isotopic ratios remain around these values for the rest of Unit 7, except for one short positive excursion at $25 \mathrm{~m}$ with values up to $2.4 \%$. The $\delta^{18} \mathrm{O}_{\text {carb }}$ values are mostly around $-9.5 \%$ with two excursions toward less negative values at $-7.3 \%$ between 2 and $5 \mathrm{~m}$ and at $-8.0 \%$ between 20 and $22 \mathrm{~m}$. At $25 \mathrm{~m}$, the sample displays a value at $-3.8 \%$. The ${ }^{87} \mathrm{Sr} /{ }^{86} \mathrm{Sr}$ values are around 0.708047 and 0.708284 .

The $\delta^{13} \mathrm{C}_{\text {carb }}$ are unusually negative $(-7.1 \%$ to $-1 \%$ ) and show a trend that does not correspond to any other described sections (Payne et al., 2004; Richoz, 2006; Horacek et al., 2007 and 2009). 


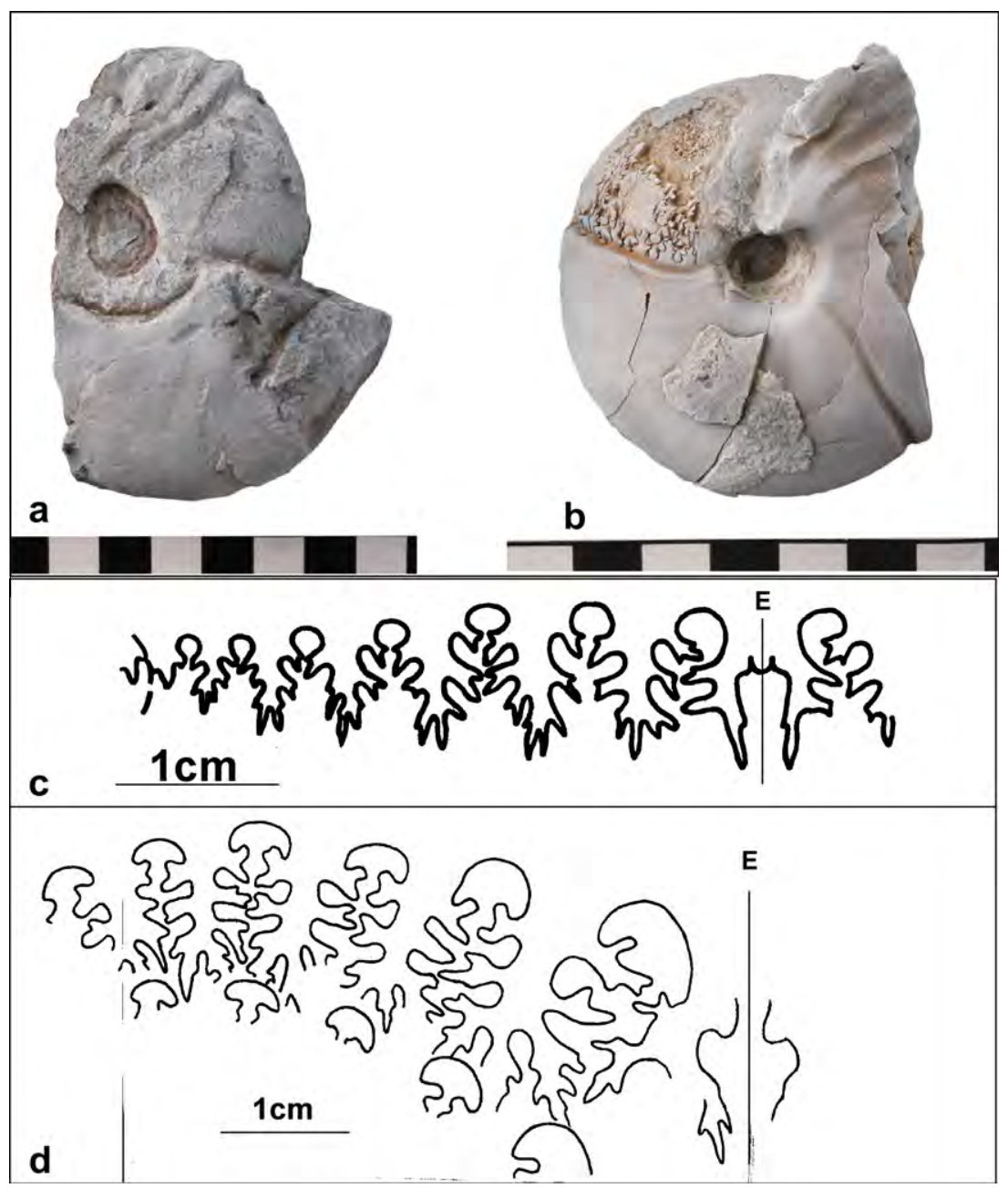

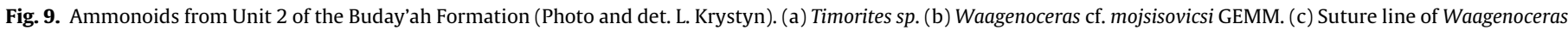
cf. mojsisovicsi GEMM. (d) Suture line of Timorites $s p$.

At the same time the ${ }^{87} \mathrm{Sr} /{ }^{86} \mathrm{Sr}$ values differ significantly from any other data set from the same time interval (Korte et al., 2004). All of these characteristics indicate a probable diagenetic overprint for the $\delta^{13} \mathrm{C}_{\text {carb }}$ and ${ }^{87} \mathrm{Sr} /{ }^{86} \mathrm{Sr}$ results and these are not interpreted further.

\section{3. $\delta^{13} C_{\text {org }}$ and geochemical results (Figs. 12 and 13)}

The $\delta^{13} \mathrm{C}_{\text {org }}$ curve in Fig. 12 shows two abrupt negative shifts. The first shift at $6.1 \mathrm{~m}$ immediately overlies the single occurrence of the conodonts $C$. cf. meishanensis and C. zhejiangensis (?), suggesting that it can be correlated with the shift found during the Late Permian extinction event (e.g. Magaritz et al., 1992; Wang et al., 1994; Grasby and Beauchamp, 2008). The second shift at $9.5 \mathrm{~m}$ is just above the occurrence of $H$. parvus reported by Richoz (2006).

Geochemical data across the Buday'ah section are shown in Fig. 13 (Units 1-5) and are relatively consistent with no significant variation in geochemical parameters. The contact between Units 5 and 6 shows slightly enriched redox sensitive trace elements, increased total organic carbon content (TOC) and the highest $\delta^{13} \mathrm{C}$ organic values in the section. The $\delta^{13} \mathrm{C}_{\text {org }}$ values drop at the extinction boundary (base of the first carbonate), associated with a second spike in redox sensitive elements. These trends are consistent with anoxic events recognized globally at or near the LPE event in deep water or basinal sediments (Isozaki, 1997; Grasby and Beauchamp, 2009).

\section{Chronology}

During the Capitanian, pillow lava of Unit 1 were filled by red lime mudstone (Unit 2) as shown by ammonite and foraminifers. The top of the red limestone is late Capitanian as indicated by conodonts. The main phase of radiolarian chert sedimentation occurred during the late Capitanian-Wuchiapingian while shale, rich in biogenic silica, accumulated until the late Changhsingian. The first drop in $\delta^{13} \mathrm{C}_{\text {org. }}$. has been described in Iran as occurring around the event-boundary in the top $C$. changxingensis Zone and at the beginning of the Hindeodus praeparvus-C. meishanensis Zone (Richoz et al., 2010). This correlates with the presence at the same level of $C$. cf. meishanensis and C. zhejiangensis(?). In Iran the $H$. praeparvus-C. meishanensis Zone is characterized by stable carbon isotopic values with a small positive peak at the top, before decreasing again until the base of the H. parvus Zone (Richoz et al., 2010). This is identical to the pattern observed here (Fig. 12) below the first occurrence of $H$. parvus in the section. The meishanensis Zone thus more or less corresponds to most of Unit 5. Unit 6 is Griesbachian to Dienerian based on conodonts. Unit 7 is correlated with the middle Smithian romunderi Zone. Some hiatuses, not demonstrated, could occur, especially in the Lower Changhsingian and Dienerian-Lower Smithian successions. 


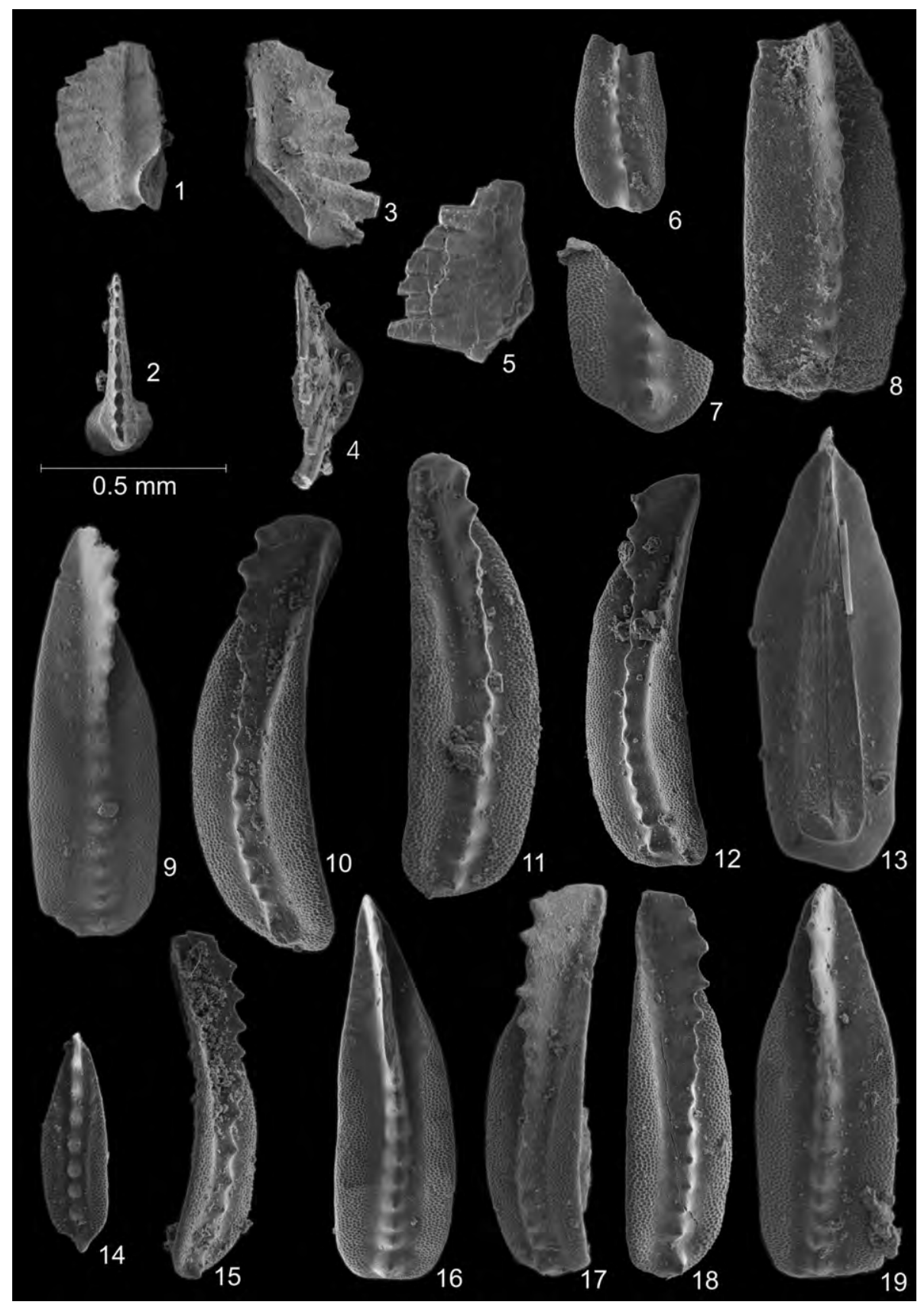

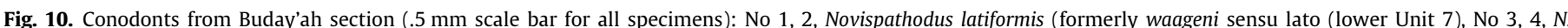

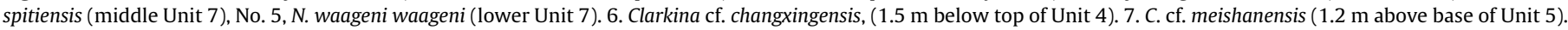

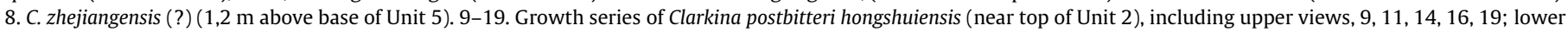
view, 13; and oblique lateral views, 10, 12, 15, 17, 18.

Unit 8 is not dated, but could be Spathian-Anisian in age based on lithologic similarities with the Maqam section (Richoz, 2006).

\section{Discussion}

The new stratigraphic data presented here can be compared with existing sedimentary cycle models for the Khuff, Saiq and Mahil formations (Koehrer et al., 2010) and the Bih and Hagil formations (Maurer et al., 2009). The pillow lavas of Unit 1 correspond to continental break-up, the opening of a new ocean and to transgression on the Arabian margin, an event that is correlated with cycle KS6 of the Saiq Formation. The pillow lava were filled and later covered by red lime mudstone (Unit 2) during the Capitanian, which is correlated with cycle KS5 (Fig. 14). The red lime mudstone sedimentation gave way to deep-water siliceous mudstone during the late Capitanian due to increasing relative sea level rise associated with the onset of thermal subsidence. The main radiolarian chert sedimentation (Unit 3, correlated with the KS4 cycle) occurs during the Wuchiapingian. The siliceous transition from dark shale to light calcareous shale occurred during the late Changhsingian. Unit 4 and part of Unit 5 are correlated with cycle KS3. The top of Unit 5 and lower part of Unit 6 are correlated with cycle KS2 (Fig. 14).

It is interesting to note that the Permian-Triassic transition did not occur at the lithologic change, but at least four meters above 


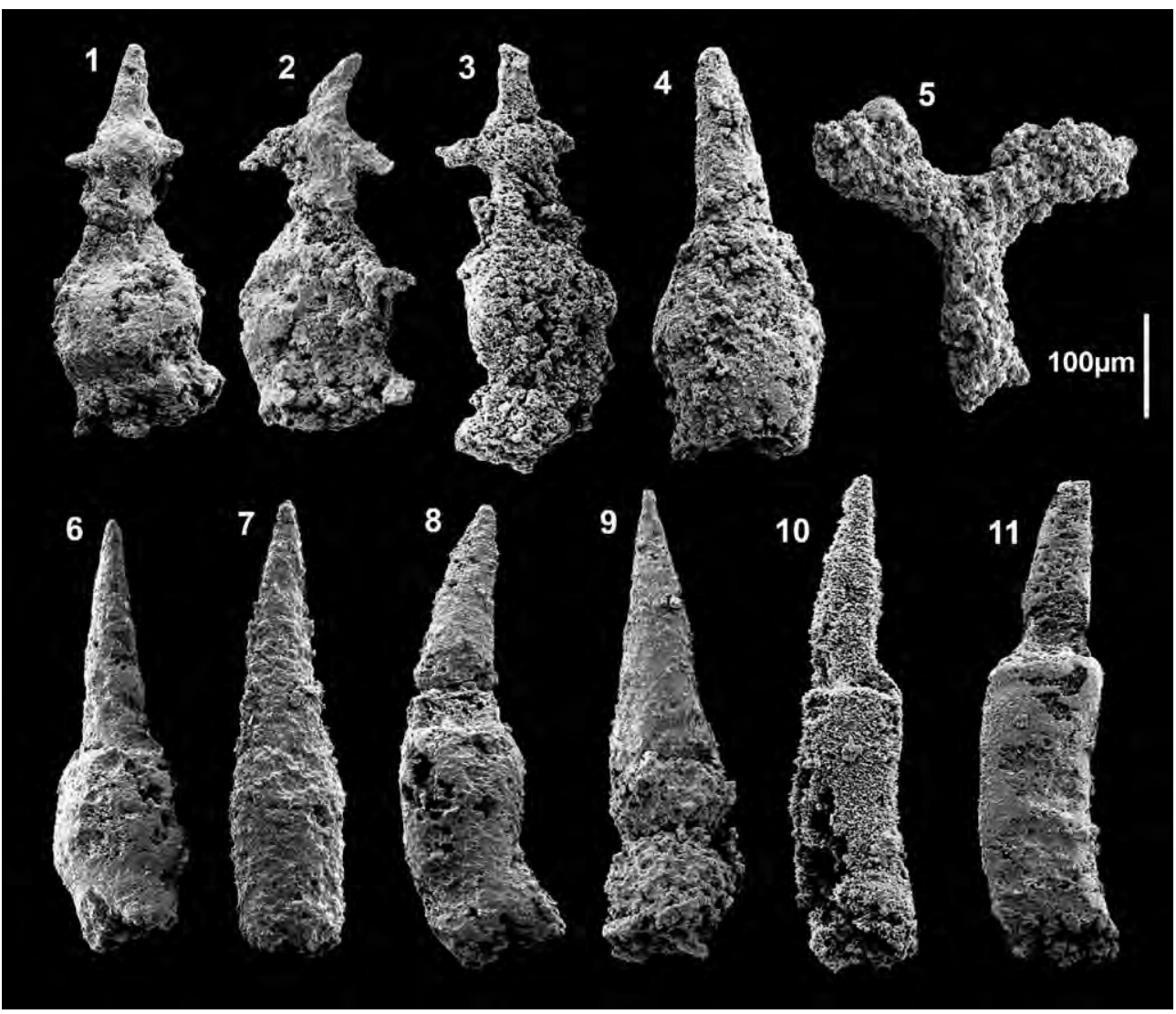

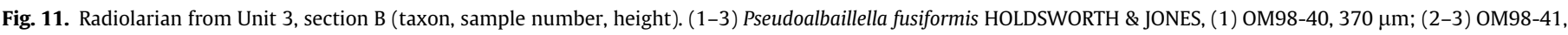

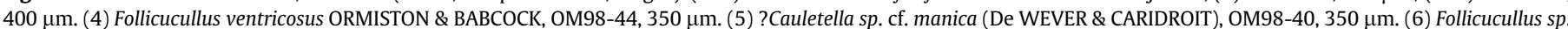

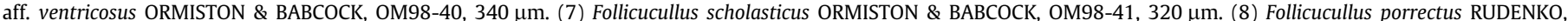
OM98-46, $400 \mu \mathrm{m}$. 9-11. Follicucullus sp., OM98-41, $400 \mu \mathrm{m}$.

the base of the light calcareous shale within the platy lime mudstone beds of the upper Unit 5, just above the base of the correlated KS2 cycle.

The microsphere horizons of upper Unit 6 (Figs. 7D and 14) are similar to well dated concentrations or blooms of "spheroids" in Tulong (S. Tibet) of late Griesbachian age (Brühwiler et al., 2009) and in Laolongdong (Sichuan, China, Wignall and Twitchett, 1996).

Neotethys extension culminated with the formation of a continental slope (Sumeini) and a basin (Hawasina) that constituted, alongside the adjacent Arabian Platform, the southern continental passive margin of the Neo-Tethys in Early Guadalupian time. Furthermore, early-rifted blocks detached from the edge of the Arabian shield formed isolated proximal platforms along the continental slope (Figs. 15 and 16).

\subsection{Comparison with other Permian basinal facies known in the Hawasina Nappes}

Basinal facies of the Middle Permian are present in the Hawasina Nappes (Fig. 16) at the base of numerous tectonics units, comprising formations from the Hamrat Duru Group. These units generally start with thick volcanic sequences assigned to the lower Al Jil Formation. They are particularly well exposed to the north of the Djebel Akhdar (Al Ajal, Nahkl and Rustaq region) and on the southern flank of the Saih Hatat (Wadi Wasit area). These volcanic rocks predominantly comprise tubular pillow basalt and subordinate andesitic and trachytic lava, transitional hyaloclastite and tuff (Béchennec, 1988; Béchennec et al., 1991, 1992a,b,c, Pillevuit, 1993; Pillevuit et al., 1997). These volcanic rocks are either of
MORB type or alkali basalt-related. However N-MORB (depleted) has not been found as most of the studied samples range from

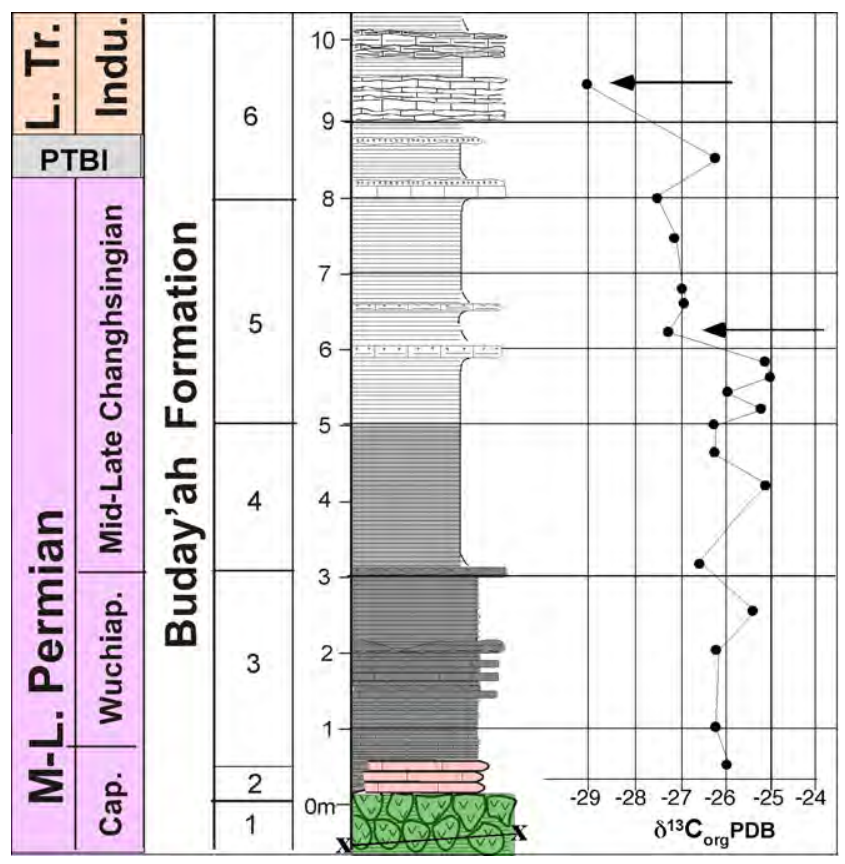

Fig. 12. The lower Buday'ah Formation with $\delta^{13} \mathrm{C}_{\mathrm{org}}$ curve. Arrows for the 2 main negative shifts (S. Grasby and B. Beauchamp). 


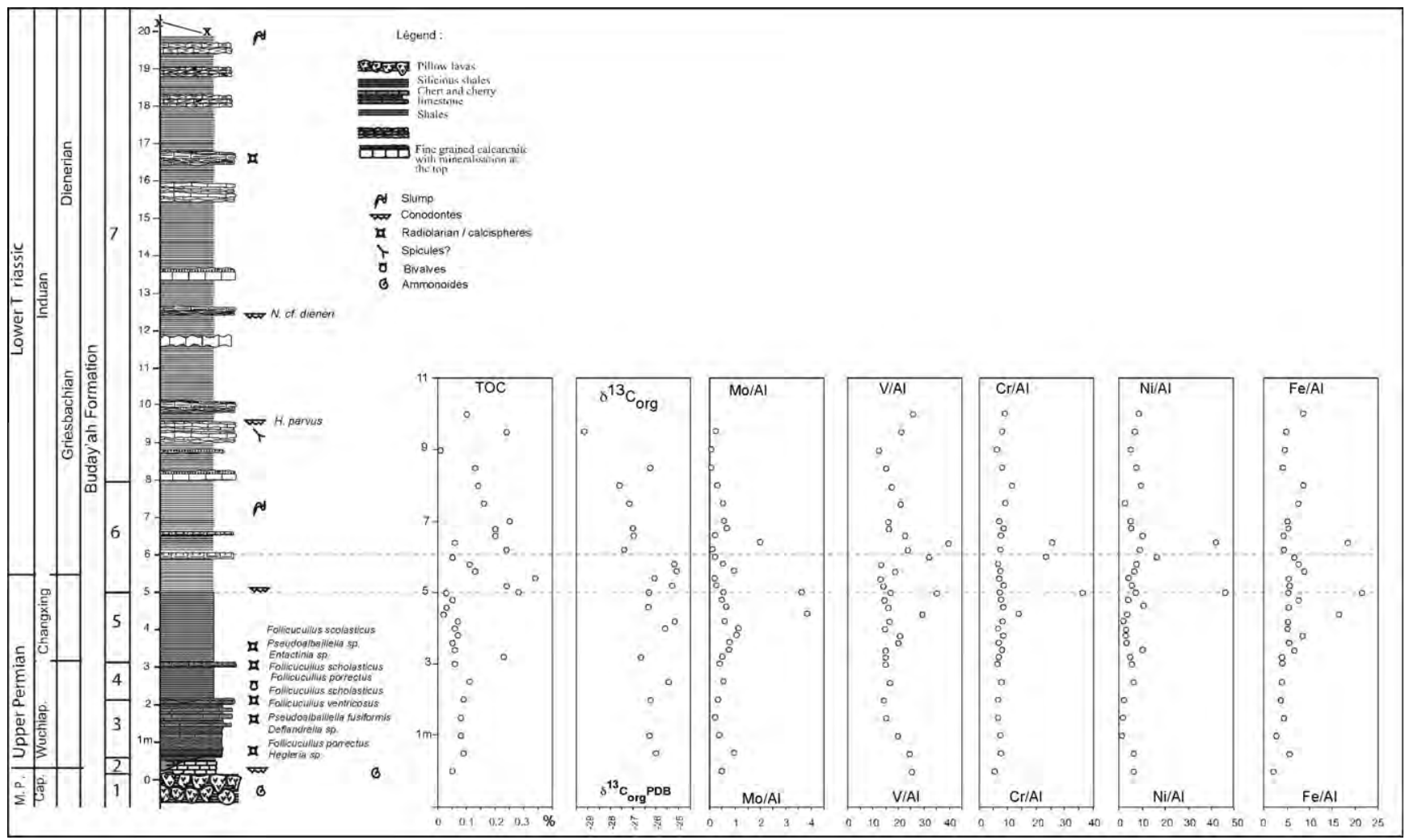

Fig. 13. Chemostratigraphy of the lower part of the Buday'ah section (S. Grasby and B. Beauchamp).

MORB to enriched MORB (Maury et al., 2003; Lapierre et al. 2004; Chauvet et al. 2009).

The volcanic succession is interstratified and overlain by red ammonoid limestone dated as Middle Permian (Roadian-Wordian) at Rustaq (Blendinger et al., 1992; Pillevuit et al., 1997; Baud et al., 2001b; Henderson and Mei, 2003; Richoz et al., 2005). In the Wadi Wasit area, this red cephalopod-bearing carbonate unit (Blendinger, 1988; Pillevuit et al., 1997; Baud et al., 2001b; Richoz et al., 2010 ) is overlain by nodular, cherty and turbiditic (allodapic) limestone. After a stratigraphic gap of nearly 10 Myrs, the Lower Triassic record begins with Dienerian breccias containing reworked blocks of Middle Permian to basal Triassic platform carbonate (Béchennec et al., 1992b; Pillevuit, 1993; Pillevuit et al., 1997; Weidlich and Bernecker, 2007; Krystyn et al., 2003; Twitchett et al., 2004; Richoz et al., 2010). In close proximity to tilted blocks or isolated as distal plateaus, all of these Permian basinal sediments lay above the Calcite Compensation Depth (CCD) and are overlain by clastic carbonate, breccia or debris flows of Late Permian or Early Triassic age. In contrast, the Buday'ah section represents an area of deep-water accumulation below the CCD and far away from slope debris flows (Fig. 16).

\subsection{Chert gap}

Our Tethyan oceanic section is comparable with published Panthalassa sections in that all localities display radiolarian bedded chert as the dominant lower Upper Permian lithology. A significant decrease of siliceous bioproductivity is recorded during the latest Permian, but more research is needed to evaluate the exact duration of this decrease. During the late Changhsingian, deep-water oceanic successions grade into a so-called "boundary shale" and/ or into poorly bedded siliceous claystone (grey shale) of variable thicknesses (Isozaki, 1994; Kakuwa, 1996; Cordey et al., 1999;
Takahashi et al., 2009). In the Buday'ah section, a lower Changhsingian chert gap is assumed because of the lack of latest Permian radiolarians at that level.

The so-called "Early Triassic Chert Gap" is a phenomenon of near global extent for which a satisfying explanation has yet to be suggested. Alongside the contemporaneous "coal gap" and the "reef gap", the absence of Early Triassic biogenic chert, following a Middle to Late Permian interval of widespread chert accumulation (Permian Chert Event of Murchey and Jones, 1992; see also Beauchamp and Baud, 2002), attests for the significant and lasting environmental deterioration that occurred across the Permian-Triassic transition. It is only in southern Panthalassa that chert deposition appeared to have been continuous (Arrow Rock, New Zealand, Takemura et al., 2002; Spörli et al., 2007). The intertropical Panthalassa oceanic sections are devoid of carbonates and biogenic siliceous sediments, which reappear progressively up section near the end of the Lower Triassic.

The chert gap is of longer duration in the Tethys (12 Myrs) than in Panthalassa Mino-Tamba terrane (6 Myrs) or Cache Creek terrane (10 Myrs). There is no chert gap, at least locally, in Southern Panthalassa as suggested by the distinctive New Zealand record.

\section{Conclusions}

The Buday'ah locality displays an important succession in the southern Neotethys margin where Guadalupian pelagic limestone is overlain by Lopingian radiolarite facies, Changhsingian siliceous and calcareous shale, followed by laminated platy Induan limestone and shale and Olenekian papery limestone and olive colored shale. The new chronology of the Buday'ah section (Fig. 14) better constrains the geodynamic evolution and early development of the southern Neotethyan margin, as summarized here: 


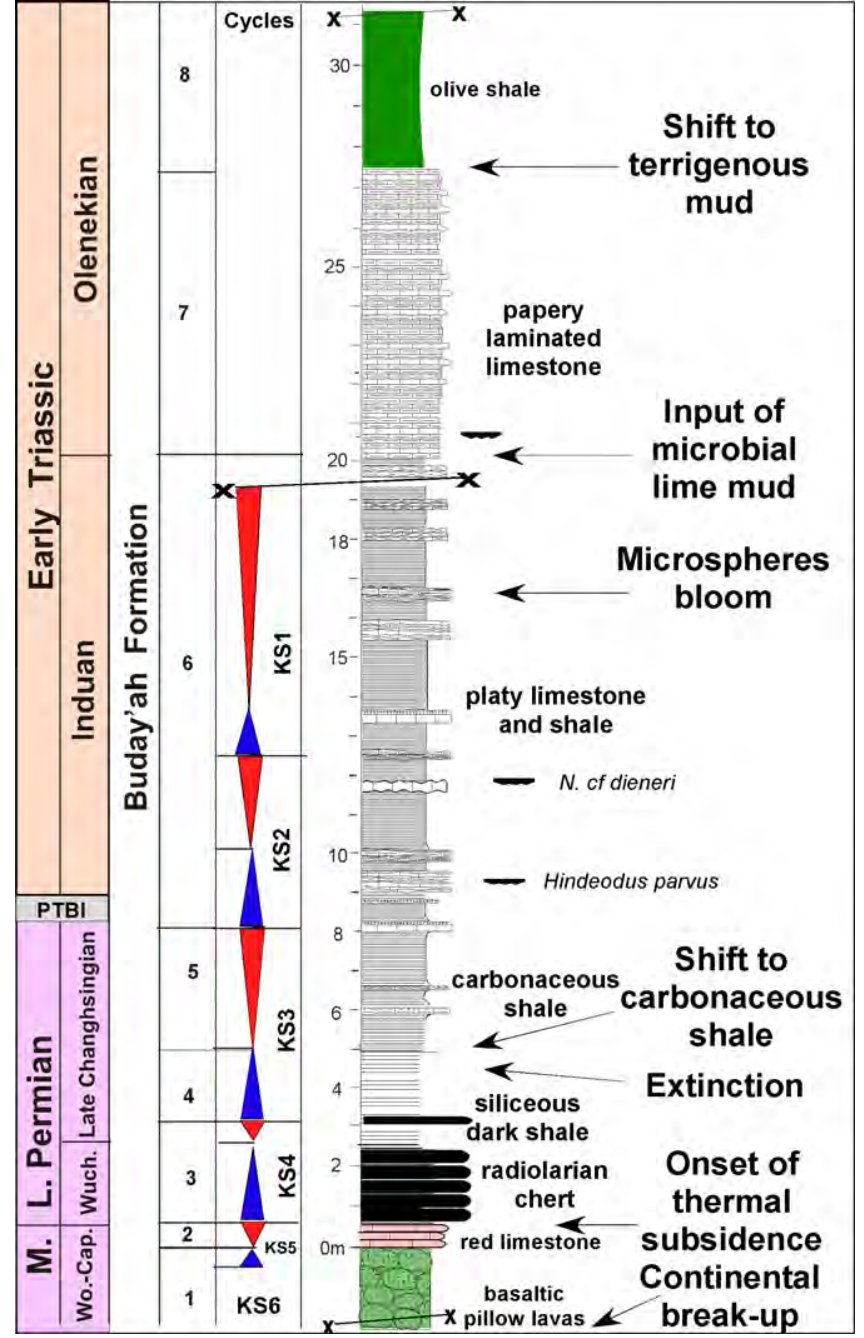

(1) Deposited on new oceanic crust, the red ammonoid limestone unit of Buday'ah (Late Wordian-Capitanian) is younger than similar red limestone units lying on pillow-basalt of thinned continental crust from the Neotethyan margin such as Rustaq or Wadi Wasit (Roadian, Henderson and Mei, 2003).

(2) The rapid change from open marine red ammonoid limestone (late Capitanian; $260 \mathrm{Ma}$ ) to deep water radiolarian shale and radiolarite characterizes the onset of thermal subsidence, some 10 Myrs after initial continental breakup that resulted in the opening of the Neotethys Ocean (Fig. 14).

(3) A change from radiolarian chert to siliceous claystone, with few radiolarian fossils, occurs in mid-Changhsingian time.

(4) The Permian-Triassic transition as recorded four meters above the lithologic change from siliceous claystone to calcareous shale, occurs within the first platy lime mudstone beds.

(5) The upper Griesbachian bloom of small calcite-filled spheres (radiolaria?, Figs. 7D and 14) as recorded at the top of the bedded platy lime mudstone and siltstone (Unit 6) seems to be a worldwide event that occurred along the distal continental margin or in the proximal oceanic realm. It might be an indicator of early radiolarian recovery in areas close to the continent.

(6) The lower Olenekian papery limestone is an unusual deep water facies of micro-cyclic, laminated, unburrowed lime mud sediment. This facies is indicative of hypoxia in association with reduced oceanic circulation

(7) During the Early Triassic, microbial carbonate factories accumulated near the Tethyan margin in proximity to the oceanic realm. The carbonate material occurs as lime mud and silt to form platy or papery limestone in the Buday'ah part of the basin during the Induan and at least part of the Olenekian. Radiolarite sedimentation resumed only during the late Anisian or early Ladinian in the Hawasina Basin.

Fig. 14. The Buday'ah Formation with the correlated Saiq cycles KS5 to KS1 and the main oceanic events.

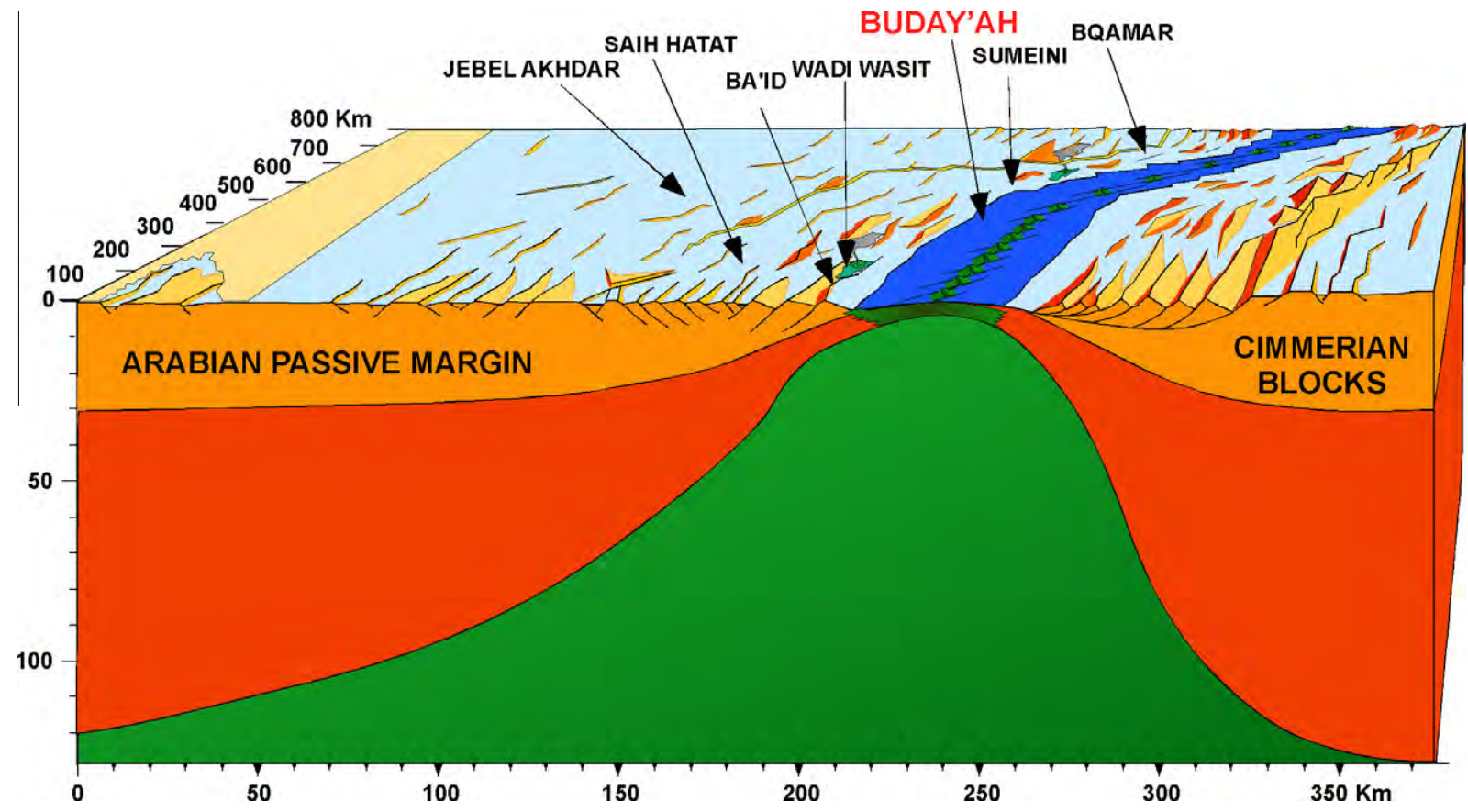

Fig. 15. Geological sketch in 3D of the Neotethys opening in Early Guadalupian time (modified from Pillevuit 1993). 


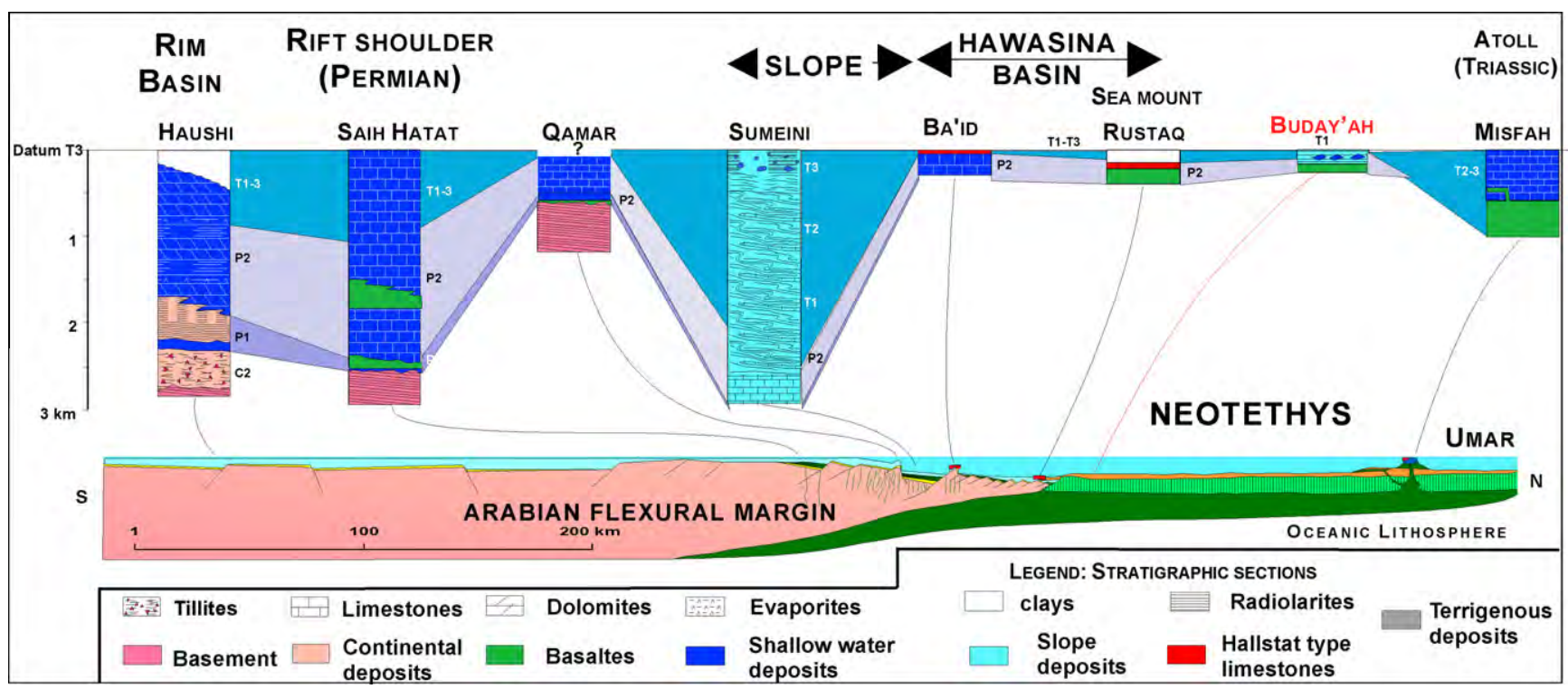

Fig. 16. Sketch of the Oman margin during the Late Triassic with the location of eight stratigraphic sections (modified from Pillevuit et al., 1997).

\section{Acknowledgements}

We are particularly grateful to Dr. Hilal bin Mohammed Al-Azri, former Director General of Minerals, for his kindness, his interest and encouragement to our past fieldwork and research in Oman. Some of us (A.B., B.B, L.K., S.G., C.H., J.M., and S.R.) are very grateful to Dr. Jean-Paul Breton and his wife Françoise for their generous hospitality and their valuable help to resolve many logistic problems that relate to fieldwork preparation and sample shipment.

The Buday'ah section has been the topic of a 1-day field workshop of the IGCP Project 572, February 24, 2010-thanks to Michaela Bernecker and the German University of Technology (Muscat) for the organization, and of a 1 day-day excursion for the Geological Society of Oman, January 20, 2011-thanks to Dr. Mohamed Al Kindly for the preparation.

A. Baud and S. Richoz appreciate the hospitality of the Geological Museum in Lausanne, of the Institute of Mineralogy and Petrography and the Institute of Geology and Paleontology, University of Lausanne for their Laboratory works. C.M. Henderson and B. Beauchamp acknowledge support from NSERC Discovery Research Grants. L. Krystyn has been supported by the Austrian National Committee for IGCP (Project 572).

The reviewers Y. Isozaki and I. Metcalfe greatly help to improve the manuscript.

\section{References}

Angiolini, L., Balini, M., Garzanti, E., Nicora, A., Tintori, A., 2003a. Gondwanan deglaciation and opening of Neotethys: the Al Khlata and Saiwan Formations of Interior Oman. Palaeogeography, Palaeoclimatology, Palaeoecology 196, 99123.

Angiolini, L., Balini, M., Garzanti, E., Nicora, A., Tintori, A., Crasquin, S., Muttoni, G., 2003b. Permian climatic and paleogeographic changes in Northern Gondwana: the Khuff Formation of Interior Oman. Palaeogeography, Palaeoclimatology, Palaeoecology 191, 269-300.

Baud, A., Béchennec, F., Cordey, F., Krystyn, L., Le Métour, J., Marcoux, J., Maury, R., Richoz, S., 2001a. Permo-Triassic Deposits: from the Platform to the Basin and Seamounts. In: Conference on the Geology of Oman, Muscat, Oman, Field Guidebook A01, pp. 1-54.

Baud, A., Béchennec, F., Cordey, F., Le Métour, J., Marcoux, J., Maury, R., and Richoz, S., 2001b. Permo-Triassic deposits: from shallow water to base of slope. In: Conference on the Geology of Oman, Muscat, Oman. Field Guidebook B01, pp. $1-40$.
Baud, A., Marcoux, J., Guiraud, R., Ricou, L.E., Gaetani, M., 1993. Late Murgabian (266 to $264 \mathrm{Ma}$ ). In: Dercourt, J., Ricou, L.E., Vrielynck, B. (Eds.), Atlas Tethys Palaeoenvironmental Maps, Explanatory Notes. Gauthier-Villars, Paris, pp. 921.

Baud, A., Richoz, S., Beauchamp, B., Cordey, F., Grasby, S., Henderson, C., Krystyn, L., 2010. The Permian-Triassic transition in the Buday'ah area. In: Baud, A Bernecker, M. (Eds.), The Permian-Triassic transition in the Oman Mountains. IGCP 572 Field Guide Book GUtech, Muscat, pp. 65-78.

Beauchamp, B., Baud, A., 2002. Growth and demise of Permian biogenic chert along NW Pangea: evidence for northern sea ice, thermohaline circulation and endPermian global warming. Palaeogeography, Palaeoclimatology, Palaeoecology 184, 37-63.

Béchennec, F., 1988. Géologie des nappes d'Hawasina dans les parties orientales et centrales des montagnes d'Oman. Documents du Bureau de Recherches Géologiques et Minières (Orléans, France) 127, 1-474.

Béchennec, F., Roger, J., Le Métour, J., Wyns, R., 1992a. Explanatory notes to the Geological map of Seeb, Sheet NF40-03. Directorate General of Minerals, Oman Ministry of Petroleum and Minerals, 104.

Béchennec, F., Roger, J., Le Métour, J., Wyns, R., Chevrel, S., 1992b. Explanatory notes to the Geological Map of Ibri, Sheet NF40-02. Directorate General of Minerals, Oman Ministry of Petroleum and Minerals, pp. 1-94.

Béchennec, F., Wyns, R., Roger, J., Le Métour, J., Chevrel, S., 1992c. Explanatory Notes to the Geological Map of Nazwa, Sheet NF40-07. Directorate General of Minerals, Oman Ministry of Petroleum and Minerals, 91p.

Béchennec, F., Tegyey, M., Le Métour, J., Lemière, B., Lescuyer, J.L., Rabu, D., Milési J.P., 1991. Igneous rocks in the Hawasina Nappes and the Hajar supergroup Oman mountains: their significance in the birth and evolution of the composite extentional margin of Eastern Tethys. In: Peters et al. (Eds.), Ophiolite genesis and evolution of the oceanic lithosphere. Ministry of Petroleum and Minerals, Sultanate of Oman, Muscat, pp. 593-611.

Besse, J., Torcq, F., Gallet, Y., Ricou, L.E., Krystyn, L., Saidi, A., 1998, Late Permian to Late Triassic palaeomagnetic data from Iran: constraints on the migration of the Iranian block through the Tethyan Ocean and initial destruction of Pangaea. Geophysical Journal International 135, 77-92.

Blendinger, W., 1988. Permian to Jurassic deep water sediments of the Eastern Oman mountains: their significance for the evolution of the Arabia margin of South Tethys. Facies 19, 1-32.

Blendinger, W., Furnish, W.M. Glenister, B.F, 1992 Permian cephalopod limestones, Oman Mountains: evidence for a Permian seaway along the northern margin of Gondwana. Palaeogeography, Palaeoclimatology Palaeoecology 93, 13-20.

Brühwiler, T., Goudemand, N., Galfetti, T., Bucher, H., Baud, A., Ware, D., Hermann, E., Hochuli, P.A., Martini, R., 2009. The Lower Triassic sedimentary and carbon isotope records from Tulong (South Tibet) and their significance for Tethyan palaeoceanography. Sedimentary Geology 222, 314-332.

Chauvet, F., Dumont, T., Basile, C., 2009. Structures and timing of Permian rifting in the central Oman Mountains (Saih Hatat). Tectonophysics 475, 563-574.

Cordey, F., 1998. Radiolaires des complexes d'accrétion de la Cordillère canadienne (Colombie-Britannique). Geological Survey of Canada, Bulletin 509, 1-209.

Cordey, F., Marcoux, J., Bucher, H., Girard, C., Lécuyer, C., Crasquin-Soleau, S., Baud, A., Orchard, M., 1999. Record of the Permo-Triassic Crisis in Oceanic Environments: New Targets in Oman, Nevada, and British Columbia, EUG 99, Strasbourg, Abstract Book, p. 275. 
De Wever, P., Bourdillon-De-Grissac, C., Bechennec, F., 1988. Découverte de radiolaires Permiennes au bord Sud de la Tethys (nappes d'Hawasina, Sultanat d'Oman). Comptes-rendus Académie des Sciences Paris 307 (II), 1383-1388.

Gaillot, J., Vachard, D., 2007. The Khuff formation (Middle East) and time equivalents in Turkey and South China: biostratigraphy from Capitanian to Changhsingian times (Permian), new foraminiferal taxa, and palaeogeographical implications. Coloquios de Paleontología 57, 37-223.

Gemmellaro, G.G., 1887. La fauna dei calcari con Fusulina della valle del fiume Sosio nella provincia di Palermo. Giornale Science Naturale ed Economia 19, 1-106.

Grasby, S.E., Beauchamp, B., 2008. Intrabasin variability of the carbon-isotope record across the Permian-Triassic transition, Sverdrup Basin, Arctic Canada. Chemical Geology 253, 141-150.

Grasby, S.E., Beauchamp, B., 2009. Latest Permian to Early Triassic basin-to-shelf anoxia in the Sverdrup Basin, Arctic Canada. Chemical Geology 264, 232-246.

Henderson, C.M., Mei, S.L., 2003. Stratigraphic versus environmental significance of Permian serrated conodonts around the Cisuralian-Guadalupian boundary: new evidence from Oman. Palaeogeography Palaeoclimatology Palaeoecology 191, 301-328.

Henderson, Charles M., Mei, Shilong, Wardlaw, Bruce R. 2002. New conodont definitions at the Guadalupian-Lopingian Boundary. In: Hills, L.V., Henderson, C.M., Bamber E.W. (Eds.), Carboniferous and Permian of the World. Canadian Society of Petroleum Geologists Memoir 19, pp. 725-735.

Horacek, M., Brandner, R., Abart, R., 2007. Carbon isotope record of the P/T boundary and the Lower Triassic in the Southern Alps: Evidence for rapid changes in storage of organic carbon. Palaeogeography, Palaeoclimatology, Palaeoecology 252, 347-354.

Horacek, M., Koike, T., Richoz, S., 2009. Lower Triassic $\delta^{13} \mathrm{C}$ isotope curve from shallow-marine carbonates in Japan, Panthalassa realm: confirmation of the Tethys $\delta^{13} \mathrm{C}$ curve. Journal of Asian Earth Science 36, 481-490.

Isozaki, Y. 1994. Superanoxia across the Permo-Triassic boundary: Record in accreted deep-sea pelagic cherts in Japan. In: Embry, A.F., Beauchamp, B., Glass, D.J. (Eds.), Pangea. Global Environments \& Resources. Canadian Society of Petroleum Geologists Memoir 17, pp. 805-812.

Isozaki, Y., 1997. Permo-Triassic boundary Superanoxia and stratified superocean records from lost deep sea. Science 276, 235-238.

Kakuwa, Y., 1996. Correlation between the bedded chert sequence of southwest Japan and $\delta^{13} \mathrm{C}$ excursion of carbonate sequence, and its significance to the Permian-Triassic mass extinction. The Island Arc 5, 194-202.

Koehrer, B., Zeller, M., Aigner, T., Poeppelreiter, M., Milroy, P., Forke, H., Al-Kindi, S 2010. Facies and stratigraphic framework of a Khuff outcrop equivalent: Saiq and Mahil formations, Al Jabal al-Akhdar, Sultanate of Oman. GeoArabia 15, 91156.

Korte, C., Kozur, H.W., Joachimski, M.M., Strauss, H., Veizer, J., Schwark, L., 2004 Carbon, sulfur, oxygen and strontium isotope records, organic geochemistry and biostratigraphy across the Permian/Triassic boundary in Abadeh, Iran International Journal of Earth Sciences 93, 565-581.

Krystyn, L., Richoz, S., Baud, A., Twitchett, R.J., 2003. A unique Permian-Triassic boundary section from the Neotethyan Hawasina Basin, Central Oman Mountains. Palaeogeography, Palaeoclimatology, Palaeoecology 191, 329-344.

Kuwahara, K., Yao, A., Yao, J., Li, J., 2004. Late Permian radiolarians and sponge spicules from the Tongtianyan section, Liuzhou, Guangxi, China. Journal Geoscience Osaka City University 47, 85-99.

Lapierre, H., Samper, A., Bosch, D., Maury, R.C., Bechennec, F., Cotten, J., Demant, A Brunet, P., Keller, F., Marcoux, J., 2004. The Tethyan plume: geochemica diversity of Middle Permian basalts from the Oman rifted margin. Lithos 74 167-198.

Magaritz, M., Krishnamurthy, R.V., Holser, W.T., 1992. Parallel trends in organic and inorganic carbon isotopes across the Permian/Triassic boundary. American Journal of Science 292, 727-739.

Maurer, F., Martini, R., Rettori, R., Hillgärtner, H., Cirilli, S., 2009. The geology of Khuff outcrop analogues in the Musandam Peninsula, United Arab Emirates and Oman. GeoArabia 14, 125-158.

Maury, R.C., Bechennec, F., Cotten, J., Caroff, M., Cordey, F., Marcoux, J., 2003. Middle Permian plume-related magmatism of the Hawasina Nappes and the Arabian Platform: Implications on the evolution of the Neotethyan margin in Oman. Tectonics, 22. Art. no.-1073.

Mojsisovics, E., 1892. Die Hallstätter Entwicklung der Trias. Sitzber. Ak.d. Wiss Wien, Math.-natw. 101, 769-780.
Mojsisovics, E., 1893. Das Gebirge um Hallstatt. Teil 1.Die Cephalopoden der Hallstätter Kalke. Abhandlungen der kaiserlich-königlichen Geologischen Reichsanstalt in Wien 6 (2), 123-147.

Murchey, B.L., Jones, D.L., 1992. A mid-Permian chert event: widespread deposition of biogenic siliceous sediments in coastal, island arc and oceanic basins. Palaeogeography, Palaeoclimatology, Palaeoecology 96, 161-174.

Orchard, M.J., Zonneveld, J.-P., 2009. The Lower Triassic sulphur mountain formation in the Wapiti Lake area: lithostratigraphy, conodont biostratigraphy, and a new biozonation for the Lower Olenekian (Smithian). Canadian Journal of Earth Sciences 46, 757-790.

Payne, J.L., Lehrmann, D.J., Wei, J.Y., Orchard, M.J., Schrag, D.P., Knoll, A.H., 2004. Large perturbations of the carbon cycle during recovery from the end-permian extinction. Science 305, 506-509.

Pillevuit, A., 1993. Les Blocs Exotiques du Sultanat d'Oman. Evolution paléogéographique d'une marge passive flexurale. Mémoires de Géologie (Lausanne) 17, 1-249.

Pillevuit, A., Marcoux, J., Stampfli, G., Baud, A., 1997. The Oman exotics: a key to the understanding of the Neotethyan geodynamic evolution. Geodinamica Acta 10, 209-238.

Richoz, S., 2006. Stratigraphie et variations isotopiques du carbone dans le Permien supérieur et le Trias inférieur de la Néotéthys (Turquie, Oman et Iran). Mémoires de Géologie (Lausanne) 46, 1-264.

Richoz, S., Baud, A., Krystyn, L., Twitchett, R., Marcoux, J., 2005. Permo-Triassic Deposits of the Oman Mountains: from Basin and Slope to the Shallow Platform. In: 24th IAS regional Meeting, Muscat, Oman. Field Guidebook A13, pp. 1-57.

Richoz, S., Krystyn, L, Baud, A, Brandner, R., Horacek, M., Mohtat-Aghai, P. 2010. Permian-Triassic boundary interval in the Middle East (Iran and N. Oman): progressive environmental change from detailed carbonate carbon isotope marine curve and sedimentary evolution. Journal of Asian Earth Sciences 39, 236-253.

Saidi, A., Brunet, M.-F., Ricou, L.-E., 1997. Continental accretion of the Iran block to Eurasia as seen from the late Plaeozoic to early Cretaceous subsidence curves. Geodinamica Acta 10, 189-208. A

Sperling, E.A., Ingle, J.C., 2006. A Permian-Triassic boundary section at Quinn River Crossing, northwestern Nevada, and implications for the cause of the Early Triassic chert gap on the western Pangean margin. Geological Society of America Bulletin 118, 733-746.

Spörli, K.B., Takemura, A., Hori, R.S., 2007. The oceanic Permian/Triassic boundary sequence at arrow Rocks (Oruatemanu), Northland, New Zealand. GNS Monograph 24, 1-229.

Spötl, C., Vennemann, T.W., 2003. Continuous-flow isotope ratio mass spectrometric analysis of carbonate minerals. Rapid Communications in Mass Spectrometry 17, 1004-1006.

Takahashi, S., Oba, M., Kaiho, K., Yamakita, S., Sakata, S., 2009. Panthalassic oceanic anoxia at the end of the Early Triassic: a cause of delay in the recovery of life after the end-Permian mass extinction. Palaeogeography Palaeoclimatology Palaeoecology 274, 185-195.

Takemura, A., Aita, Y., Hori, R.S., Higuchi, Y., Sporli, K.B., Campbell, H.J., Kodama, K., Sakai, T., 2002. Triassic radiolarians from the ocean-floor sequence of the waipapa terrane at arrow rocks, northland, New Zealand. New Zealand Journal Geology and Geophysic 45, 289-296.

Twitchett, R.J., Krystyn, L., Baud, A., Wheeley, J.R., Richoz, S., 2004. Rapid marine recovery after the end-Permian mass-extinction event in the absence of marine anoxia. Geology 32, 805-808.

Wang, K., Geldsetzer, H.H.J., Krouse, H.R., 1994. Permian-Triassic extinction: organic $\delta^{13 \mathrm{C}}$ evidence from British Columbia, Canada. Geology 22, 580-584.

Weidlich, O., Bernecker, M., 2007. Differential severity of Permian-Triassic environmental changes on Tethyan shallow-water carbonate platforms. Global and Planetary Change 55, 209-235.

Wignall, P.B., Twitchett, R.J., 1996. Facies change and the end-Permian mass extinction in S.E. Sichuan, China. Palaios 11, 587-596.

Yao, A., Kuwahara, K., 2000. Permian and Triassic radiolarians from the southern Guizhou Province, China. Journal of Geosciences, Osaka City University 43, 119.

Zhakarov, Y., Ehiro, M., 2010. New data on Guadalupian through earliest Lopingian Timorites of Far East, phylogeny, biostratigraphical and paleogeographical significance of cyclolobid ammonoids. In: Tanabe, K., Shigeta, Y., Sasaki, T., Hirano, H. (Eds.), Cephalopods - Present and Past. Tokai University Press, Tokyo, pp. 09-221. 